\title{
JAN REISNER W AKADEMII ŚW. ŁUKASZA \\ ARTYSTA A POLITYKA KRÓLA JANA III I PAPIEŻA INNOCENTEGO XI
}

Na jednej z zacienionych ścian nawy bocznej kościoła parafialnego w Węgrowie można dostrzec okrągły portret ukazujący w popiersiu mężczyznę ubranego w karmazynowy kaftan ze złotym lamowaniem z jedwabną chustą przewiązaną wokół szyi (il. 1). Godny wyraz twarzy i uczesanie włosów wskazują na wysoką pozycję społeczną zmarłego. Umieszczona poniżej inskrypcja, wykonana pozłoconymi literami na marmurowej tablicy, prezentuje splendory portretowanego, wyróżnionego honorowym tytułem Aulae Lateranensis Comes oraz Orderem Złotej Ostrogi (Aureatae Militiae Eques). Ponadto dowiadujemy się o jego profesji geometry - mierniczego królewskiego (geometra regni) oraz sprawowanej godności marszałka dworu Jana Krasińskiego, wojewody płockiego (aulae Joannis Krasinii palatyni plocensi mareschalcus). Pozornie widzimy jeden z wielu przykładów sepulkralnego upamiętnienia zmarłego, ale wyjątkowość tego przypadku w polskich realiach społecznych polega na tym, że zmarłym był Jan Reisner (ok. 1655-1713) - malarz i architekt ${ }^{1}$.

Dr hab. TADEuSz Bernatowicz, prof. UŁ, Instytut Historii Sztuki, Wydział Filozoficzno-Historyczny, Uniwersytet Łódzki; adres do korespondencji: ul. Narutowicza 65, 90-131 Łódź; e-mail: tadeusz.bernatowicz@uni.lodz.pl; ORCID: 0000-0002-8674-5307

1 Jan Reisner jako malarz został odnotowany już w XIX w. przez Edwarda Rastawieckiego (134137). Zasadnicze znaczenie dla identyfikacji Reisnera jako malarza i architekta miały artykuły Mariusza Karpowicza: „Jan Reisner” 70-83 (tam pełny tekst inskrypcji epitafijnej); „O Janie Reisnerze” 253-268; „Reisner Jan” 382-384. Próbę charakterystyki projektów konkursowych zaprezentował Gil R. Smith (Smith, Architectural Diplomacy 96-97, 122-130, 234-235, 264-265, 346-347, i1. 18-20). 


\section{PODRÓŻ JANA REISNERA DO RZYMU}

Kariera artystyczna i awans społeczny Reisnera rozwinęły się dzięki aktywności patronackiej króla Jana III Sobieskiego. Wyróżniającą inicjatywą monarchy na tle ówczesnych elit władzy w Polsce było wysłanie go razem z Jerzym Eleuterem Siemiginowskim (Szymonowiczem) na studia artystyczne do Akademii św. Łukasza w Rzymie. Prawdopodobnie towarzyszył im malarz Michael Probener, protegowany Michała A. Hackiego, późniejszego opata oliwskiego i zaufanego współpracownika króla polskiego².

Do Wiecznego Miasta stypendyści mogli się udać indywidualnie szlakiem pocztowo-podróżnym przez Wiedeń i Wenecję. W tym samym czasie nadarzała się jednak lepsza okazja dotarcia do celu. Zważywszy na wyróżniający status królewskich stypendystów i wiązane z nimi nadzieje artystyczne króla, bardziej prawdopodobne jest, że zostali powierzeni opiece królewskiego szwagra - podkanclerzego i hetmana litewskiego Michała Kazimierza Radziwiłła, który wraz z Katarzyną z Sobieskich wyruszył w podróż do Włoch. Oficjalnie celem podróży była kuracja Radziwiłłowej oraz pielgrzymka do Loreto, ale jednocześnie książę miał rozpoznanać możliwości przyszłego złożenia obediencji w imieniu Jana III papieżowi Innocentemu XI oraz uzyskania wsparcia dla polityki antytureckiej (Billewicz; Pietrzak 103-126).

Zważywszy na liczebność orszaku książęcego, włączenie do niego stypendystów nie stanowiło problemu, a co więcej - mogli oni przy tej okazji zapoznać się po drodze ze sztuką i kulturą Cesarstwa i Włoch. Okazały, niczym poselski orszak wyruszył 10 sierpnia 1677 r. z Białej i przez Cieplice, Pragę, Norymbergę, Augsburg, Innsbruck, Padwę, Wenecję, Loreto dotarł do Rzymu 24 lutego 1678 r., gdzie Radziwiłłowie pozostali do czerwca tego roku. Przybycie Reisnera i Siemiginowskiego do Rzymu na początku 1678 r. mogło zatem umożliwiać młodym adeptom edukację w Akademii św. Łukasza już w tym czasie, ponieważ rok ,akademicki” zaczynał się wczesną wiosną i kończył późną jesienią. Mogli odbyć naukę w latach 1678, 1679 i 1680, a w 1681 r., mając już zaawansowane wykształcenie, uczestniczyć w Concorso Accademico.

Pobyt w orszaku książęcym ułatwiał również zorganizowanie pobytu w Rzymie i podjęcie studiów w Akademii. Radziwiłł został przyjęty na audiencjach u papieża Innocentego XI i dostojników Stolicy Apostolskiej, jak też sam podejmował

2 Michael Probener (zm. 1701), pochodzący z Grudziądza, studiował razem z Reisnerem i Siemiginowskim. Otrzymał drugą nagrodę w pierwszej klasie malarstwa w 1681 r., w tym samym konkursie, który wygrał Siemiginowski. Jego postać została zapomniana, choć odegrał ważną rolę w rozpowszechnianiu eklektyzmu rzymskiego Akademii św. Łukasza, najpierw na Pomorzu (Oliwa), potem na dworze elektora brandenburskiego Fryderyka III. Jako malarz nadworny pełnił jednocześnie funkcję dyrektora Akademii Berlińskiej. „Probener Michael” 410. 
wpływowych kardynałów. Należał do nich ówczesny protektor Królestwa Pietro Vidoni (1676-1681) (Osiecka-Samsonowicz 148-168; Pietrzak 126). Równie ważną rolę, jeśli nie istotniejszą, dla relacji polsko-watykańskich odgrywał kardynał Carlo Barberini (1681-1704). Obu wybrał Jan III Sobieski, a funkcja protektora miała specyficzny, nie do przecenienia charakter. Zobowiązywał się on bronić interesów i prerogatyw państwa, które reprezentował na dworze watykańskim, ale jednocześnie musiał troszczyć się o sprawy Stolicy Apostolskiej. Barberini, jeszcze zanim został protektorem Polski, włączał się w sprawy związane z polskimi działaniami dyplomatycznymi w Rzymie i był postrzegany jako przychylny interesom Rzeczypospolitej ${ }^{3}$. Jego wyróżniająca się aktywność była widoczna w czasie pierwszego pobytu Radziwiłła w Rzymie w 1678 r., gdy angażował się w organizowanie kontaktów i audiencji Radziwiłła. Szczególnie wymowne dla relacji Barberiniego z Polakami było udostępnienie własnego pałacu Katarzynie Radziwiłłowej i jej fraucymerowi (Thatrum Europeum 1260-1261; Pietrzak 116). Kardynał równie aktywnie uczestniczył w wydarzeniach związanych z poselstwem z obediencją Radziwiłła w 1680 r. (Jaroszuk 105-119; Osiecka-Samsonowicz 100-123, 148-168). Już po przyjęciu funkcji protektora Polski (1681) zaprzysiągł 5 marca 1684 r., w imieniu króla polskiego, traktat powołujący Ligę Świętą. Reisner pozostawał w kontaktach z Radziwiłłem, co potwierdza jego udział w różnorodnych działaniach podczas poselstwa księcia w 1680 r. W rachunkach książęcego dworzanina Koryckiego pojawiło się nazwisko „Rezner”, które można utożsamić z naszym artystą ${ }^{4}$. Przekazywał on po audiencji podarunki solistom w uznaniu ich kunsztu oraz uregulował zaległą opłatę „za fochi pierwsze i machinę”, co wiązało się z pokazem sztucznych ogni sfinansowanych przez księcia.

3 Jako postulat badawczy można zgłosić kwerendę znaczącej liczby korespondencji między Barberinim a polskim królem i jego dworzanami. Znajdująca się w Bibliotece Watykańskiej, może nam ujawnić również ewentualne szczegóły związane ze stypendystami królewskimi. G. Platania podaje, że sekretarz osobisty króla, Tommaso Talenti, wysłał do Barberiniego ok. 650 listów, a Barberini - aż 765 „Carlo Barberini - „Protektor Królestwa Polskiego” 85).

4 Archiwum Główne Akt Dawnych Archiwum Radziwiłłowskie [dalej:AGAD AR], dz. II, ks. 2; „Rachunki Koryckiego będąc w Rzymie y w cudzych Kraiach y inne curiosa scripta”. „Rachunki wydatkow moich w Rzymie podczas Ambasiady Jasnie Oswieconego Xcia Jmsc Pana Podkanclerzego y Hetmana WXL cum Obedientia ad suam Sanctitatem Innocentium XI Summum Pontificem Anno Verbi Incarnati MDCLXXX”, s. 137 (144 - stara paginacja). „[Nr] 56. NB. Za Fochi pierwsze y Machinę dopł[aciłem] przez P. Reznera Sc[udów] ...10.

[Nr] 57. Przez ręce P. Reznera Vocalistom Papieskim dwom dałem Medagle złote XJmc, a trzem po trzy Doble czyni na Monetę Sc[udów] ...27.

Na Piąciu Jnstrumentalistow przez tegoż Sc[udów] ...36.

[Nr] 59. Od Przekopiowania Ritratta Xcia Jm Sc[udów] ...12”. 
Po przybyciu do Rzymu przed młodymi adeptami sztuki, będącymi pod opieką księcia, działającego w imieniu króla, otwierały się pełne możliwości studiowania, jakie stwarzała Akademia, której zwierzchnikiem był papież Innocenty XI (16761689) (Benedetto Odescalchi), a opiekunami - prominentni kardynałowie Kurii: Siemiginowskiego - bratanek papieża Livio Odescalchi, Reisnera - wspomniany Carlo Barberini. Ten ostatni po śmierci stryja Francesco Barberiniego w 1679 r. pełnił w imieniu papieża funkcję protektora uczelni.

2. CONCORSO ACCADEMICO $\mathrm{W} 1681 \mathrm{R}$. - PIERWSZA NAGRODA I NOBILITACJA POLAKA

Najważniejszym osiągnięciem polskich stypendystów było uzyskanie pierwszych nagród w pierwszej klasie konkursu akademickiego w roku 1681: malarskim - Siemiginowski, architektonicznym - Reisner. Choć obaj mieli kształcić się przede wszystkim w malarstwie, to Reisner przystąpił do konkursu z projektem architektonicznym, zapewne by nie konkurować ze zdolniejszym i bardziej ustosunkowanym kolegą, a interdyscyplinarna specyfika edukacji w Akademii dawała wszechstronne kompetencje artystyczne. Rekostrukcja procesu i programu nauczania w Akademii do końca XVII w. jest utrudniona ze względu na brak systematycznie prowadzonej ówcześnie dokumentacji. Sporządził ją dopiero wieloletni sekretarz - Giuseppe Ghezzi w 1699 r., obejmując czas od roku 1674, stąd odnotowano tam ważne i różnorodne informacje dotyczące funkcjonowania szkoły, pomijając jednak wiele szczegółów. Zachowany protokół z kwietnia 1681 r., odzwierciedlający jeden sezon edukacji Reisnera, określa, jakie zajęcia odbędą się między majem a październikiem i kto będzie je prowadził. Rysunku z modela mieli uczyć malarze: Lazzaro Baldi, Filippo Carcani, Luigi Garzi, Agostino Scilla, Francesco Cozza, Giovani Maria Morandi oraz rzeźbiarze Ercole Ferrata, Michele Maglia i Antonio Raggi. Anatomię wykładal Giacomo del Po, zaś perspektywę (z geometrią i matematyką) Pietro del Po5. Zajęcia z architektury miały dwojaki charakter: wykłady teoretyczne prowadził Gregorio Tommassini, natomiast praktyka odbywała się w terenie, gdzie inwentaryzowano budowle lub ich fragmenty. Później praktykowano na jakiejś budowie pod kierunkiem zawodowych architektów. Nie wiadomo, czy i gdzie terminował Reisner.

5 Archivio storico dell'Accademia di San Luca [dalej: AASL], nr 45 [Livri delle resolutioni e Decreti fatti nelle Congregationi Accademiche e Generali dalli Sig[no]ri Accademici del Disegno Pictori, Scultori et Architetti di Roma, dall Anno 1674 fino à tutto 1699 Essendo Segretario S[ign]o[r]. Giuseppe Ghezzi Pictore Potadino Assolano], k. 91v.; Karpowicz, „O Janie Reisnerze” 16-17). 
Trudno sobie wyobrazić, ażeby mógł zaprojektować na konkurs światynię ocenioną tak wysoko, bez choćby częściowej praktyki architektonicznej. Jak będzie o tym później mowa, związki architektury kościoła projektowanego na konkurs z dziełami Berniniego i Fontany zdają się wskazywać na budowy związane z tymi architektami. Wznoszono wtedy dwa centralne kościoły przy Piazza del Popolo: S. Maria di Montesanto (Carlo Rainaldi, Giovanni Lorenzo Bernini: 1662-1679) i S. Maria dei Miracoli (C. Fontana, 1675-1681). Nasz architekt mógł zdążyć zetknąć się z Berninim, który umarł 28 listopada 1680 r., jednak wpływową rolę w edukacji akademickiej tego czasu odgrywali Rainaldi (zm. 1691), a zwłaszcza Fontana.

17 maja 1681 r. władze Akademii pod kierunkiem sekretarza Gezziego określiły tematy konkursowe w klasach malarstwa, rzeźby oraz architektury ${ }^{6}$. Tommassini sformułował architektoniczne zadanie konkursowe, polegające na zaprojektowaniu kościoła. Choć nie zachowały się szczegóły soggeto, to z pewnością możemy uznać, że miała to być budowla centralna na planie koła, z kolumnową elewacją-portykiem, ale nie w typie Panteonu, jak miało to miejsce w konkursie z 1677 r., którego szczegóły sprecyzował ten sam architekt. Podczas wcześniejszych konkursów ustalono kolejność postępowania: ogłaszano tematy zadań konkursowych, ustalano dzień złożenia prac, w którym jednocześnie przeprowadzano naoczny sprawdzian umiejętności adeptów. Z kompletem rysunków zapoznawali się jurorzy, przyznawali nagrody, które w późniejszym terminie uroczyście wręczano laureatom - początkowo w ówczesnej siedzibie Akademii przy via di Ripetta, później na Kapitolu. W roku 1681 procedurę zmieniono w takim stopniu, że budzi się podejrzenie, iż w ten sposób sprzyjano Polakom w odniesieniu zwycięstwa. Do tego problemu wrócimy w dalszej części artykułu.

7 września uchwalono, że prace należy składać 12 października, jednocześnie już 13 września, jeszcze przed złożeniem rysunków, przeprowadzono prova estemporanea. Ponadto 5 października przesunięto termin przyjmowania prac na 14 grudnia, a 25 tego samego miesiąca, w drugi dzień Świąt Bożego Narodzenia (sic!), ukonstytuował się zespół jurorów, by dokonać wyboru laureatów. Do zespołu oceniającego projekty architektoniczne powinni wejść z urzędu: ówczesny principe - architekt Mattia de Rossi, sekretarz Giuseppe Gezzi oraz członkowie-architekci z Akademii, ale w końcu grudnia kadencja de Rossiego wygasła, a na rok 1682 na principe przewidziany został malarz Giuseppe Garzi (1638-1721). W efekcie to Garzi, sekretarz Gezzi, Tommassini oraz dokooptowany architekt Giovanni B. Menicucci zdecydowali o podziale nagród. Tommassini (visitator d'infermi i stimator d'architetture)

6 AASL, nr 45, k. 92. Tematy konkursowe dla malarzy i rzeźbiarzy opublikował Karpowicz („O Janie Reisnerze” 16-17). 
był teoretykiem architektury, znawcą konstruowania porządków architektonicznych, od lat wykładającym na Akademii, Meniucci - praktykiem, którego najważniejszym dziełem była budowa fasady SS. Ambrogio e Carlo al Corso w Rzymie (1682-1684) na podstawie rysunku kardynała Luigiego Omodei (1668-1669). Wcześniej Pietro da Cortona ukształtował kopułę, prezbiterium i część dekoracji wnętrza. W odnowionym zespole zarządu na rok 1682 znaleźli się ponadto Giovanni Battista Contini (stimator d'architetture) oraz malarz i architekt pochodzący z Turynu Pietro Francesco Garoli (1638-1716), prowadzący na Akademii wykłady z perspektywy (1679-1689, 1693-1695, 1698-1708). Podczas uroczystości przy via Ripetta, które odbyły się 11 stycznia 1682 r., de Rossi, jako były principe, odczytał werdykt, a Barberini wręczył nagrody w asystencji kardynałów Decio Azzoliniego, mecenasa i kolekcjonera, oraz Gaspara Carpegny, literata i konesera sztuki.

W archiwum Akademii zachowały się nazwiska wszystkich laureatów w konkursach malarskim i rzeźbiarskim z 1681 r. Niestety, w konkursie architektonicznym poza Reisnerem brakuje nazwisk drugiego i trzeciego nagrodzonego w I klasie. Rysunki związane z II klasą, w której zazwyczaj projektowano mniejszy obiekt architektoniczny, też nie są znane. Wymienione w katalogu I disegni di architettura... zadanie w III klasie, zatytułowane Ingresso ad una villa, czyli na bramę prowadzącą na teren willi, faktycznie dotyczy konkursu z 1696 r. ${ }^{7} \mathrm{Na}$ podstawie dostępnych materiałów nie sposób wyjaśnić, czy Reisner był jedynym kandydatem w konkursie, co byłoby dziwne, czy też pozostałe materiały nie zachowały się w archiwum do czasów inwentaryzacji na przełomie XVII i XVIII w. Sytuacja taka uniemożliwia ocenę wartości projektu Polaka na tle innych artystów.

W Archivio storico dell'Accademia di San Luca zachowały się trzy rysunki projektowe kościoła wykonane przez Jana Reisnera narysowane piórkiem i akwarelą przedstawiające elewację frontową (il. 2), przekrój podłużny (il. 3) oraz rzut (il. 4) . $^{8}$ Mimo że wykonane zostały na konkurs w 1681 r., opisano je z datą 1682, gdy wręczano już nagrody (Marconi, Cipriani i Valeriani 4: il. 56: „Giovanni Reizner Polacco” - na planszy z rzutem; il. 57,58: „Giovanni Reizner Polacco 1 premio 1682”

7 Identyfikacji autorów projektów oraz lat konkursów, zachowanych w Archivio storico Accademia di San Luca, dokonano w końcu XVII w., gdy porządkował je sekretarz Giuseppe Gezzi. Niektóre $\mathrm{z}$ nich zostały błędnie opisane, a następnie, według tych opisów, opublikowane w katalogu: Marconi, Angela i Valeriani. Niektóre z nich zostały skorygowane w późniejszych badaniach.

8 Rysunki Reisnera w komplecie zostały odnotowane w katalogu Marconiego, Ciprianiego i Valerianiego, w czarno-białej wersji, w złej jakości technicznej (Marconi, Ciprani i Valeriani, il. 56-58). W Polsce dwa z nich (elewacja, przekrój) upublicznił Karpowicz („Jan Reisner” 80-81, il. 9, 10). W późniejszym czasie opublikował komplet w kolorze, w dość kuriozalnej, nierecenzowanej publikacji. Rzut został zdeformowany i okrągły plan stał się owalnym (sic!) (Karpowicz „Stypendyści królewscy" 110, 113). 
- na widoku elewacji i przekroju podłużnym). Na tej podstawie uznano błędnie, że Reisner wygrał konkurs w 1682 r. Pod datą 1 listopada 1682 r. w Libro delle Resolutione et Decreti... Ghezzi odnotował, że Akademia, w osobie principe Garziego (Gharziego), z inicjatywy kardynała Barberiniego, postanowiła szczególnie uhonorować Reisnera (Giovanni Raisnier Polacco) przyjęciem go na członka Akademii (AASL, nr 45, k. 107; Karpowicz, ,Jan Reisner” 83). Nota potwierdza, że otrzymał on wcześniej I nagrodę w pierwszej klasie w konkursie architektonicznym w $1681 \mathrm{r}$. i że teraz otrzymuje patente, z czym wiąże się obowiązek przekazania czterech namalowanych przez siebie obrazów do Akademii (il quadro dipinto di sua mano). Potwierdzenie tego faktu znajdujemy w Catalogo degli Accademici di S. Luca di merito dagli anno 1673, na liście akademików spisanej na pocz. XVIII w., gdzie lapidarnie odnotowano, „Pan Giovanni Raisnier, Polak, malarz, student, 1 listopada 1682"9. Jakimi motywami kierowali się akademicy, żądając od Reisnera pozostawienia aż czterech obrazów, gdy przeważnie wystarczał jeden, jak było choćby w przypadku przyznania patente dla Siemiginowskiego? Przyznanie dyplomu należało do przejawów szczególnego uznania dla kunsztu artysty. W tym wypadku Reisner wystąpił jako malarz, nie architekt. Godność ta miała przede wszystkim charakter honorowy, choć również praktyczny - otwierała ewentualną drogę do przyszłego aktywnego uczestnictwa w pracach Akademii, w roli wykładowcy, mistrza edukującego młodszych adeptów sztuki, a nawet wyboru na principe bądź inne funkcje w szkole. W przypadku Polaków możliwości dalszego rozwoju kariery w Rzymie były bardziej niż skromne, i to nie z powodu braku talentu, ale z racji - mimo wszystko - zbyt małych patronackich koneksji w Rzymie. Tym bardziej że zobligowani zostali przez króla, by powrócić do Polski.

Opieka Barberiniego i Odescalchiego nad Polakami i ich wyróżnianie jest widoczne również w skutecznych zabiegach o przyznanie im Orderu Złotej Ostrogi (Aureatae Militiae Eques) oraz tytułu Aulae Lateranensis Comes, co było równoznaczne z nadaniem szlachectwa, potwierdzone następnie przez Jana III. Wkrótce opuścili oni Rzym, ale w Wiedniu zostali odnotowani dopiero w 13 czerwca 1683 r. jako dokonujący zakupu obrazów dla króla: „Johann Reissner und Georg Szymonowic beede Khönigl. Hoffmaler, halten an umb freijen Passbrief der vor Ihr Khönigl. Maijs. In Pohlen mitfürende Mahlereij" (Wiedeń, Hof- und Finanz Kammerarchiv, Hoffinanz, n953, f496v.-497; Duverger 176). Stolicę cesarstwa musieli niezwłocz-

9 AASL, nr 28 [„,Catalogo degli Accademici di S. Luca di merito dagli anno 1673]. k. 3. „Sig[o]r Giouanni Raisnier Polacco Pittore Studente 1o 9bre[novembre] 1682”. Odnotowano tam również: „Sig[o]r Giorgio Simonnouiz Polacco Pittore Studente 26 Luglio 1682”. Wskazywałoby to zatem, że Siemiginowski dostał patente Akademii 26 lipca 1682. Karpowicz („O Janie Reisnerze” 20), opierając się na innym zapisie archiwalnym (AASL, nr 45, k. 103v.), podaje datę 6 września $1682 \mathrm{r}$. 
nie opuścić, kierując się do kraju, w związku z nadciągającą turecką armią Kara Mustafy, która otoczyła miasto już 14 lipca 1683 r.

\section{REKONSTRUKCJA ARCHITEKTURY ŚWIĄTYNI PROJEKTU REISNERA}

Zachowane trzy plansze z projektem Reisnera umożliwiają bliższe przyjrzenie się problematyce architektonicznej i podjęcie próby rekonstrukcji architektury budowli. Artysta skomponował świątynię na planie koła, z otwierającymi się do środka ośmioma niższymi kaplicami na planach prostokątów, z wyciętymi wnękami w krótszych bokach, w których widnieją ołtarze (il. 5). W środku oznaczony został ołtarz z baldachimem, wspartym na filarowo-kolumnowych podporach (il. 6). Część prezbiterialna składa się z płytkiego, prostokątnego chóru z lekko zaokrąglonymi narożami i przylegających do niego dwóch dużych pomieszczeń - zakrystii i skarbca, połączonych korytarzem biegnącym za prezbiterium. Trzyczęściowa kruchta o nieregularnym układzie wpisuje się szerokością w ciąg kaplic i łączy się z podcieniami portyku. W rotundowym wnętrzu można wyodrębnić trzy zasadnicze części. Najniższą tworzą arkady, otwierające się do kaplic, prezbiterium i kruchty z artykulacją pilastrami korynckimi. Wyższą od niej strefę tamburu, sprawiająca optyczne wrażenie cięższej, podzielono pilastrami kompozytowymi ustawionymi na wysokich bazach, między którymi naszkicowano sceny figuralne - malowane bądź rzeźbione. Bogatą oprawę znajdujących się tam okien tworzą edikule z półplastycznymi kolumnami jońskimi zwieńczone trójkątnymi naczółkami. Na cokołach attyki wieńczącej tambur widnieją putta podtrzymujące girlandę (il. 7). We wnętrzu hemisferycznej kopuły została naszkicowana kompozycja Stracenie aniołów (il. 8). Górne doświetlenie wnętrza miała uzupełniać latarnia o ośmiu wąskich i wysokich oknach.

Projekt przewidywał nakrycie kaplic otaczających część centralną kopułkami z tamburami i latarniami. Na podstawie rysunków trudno jednak określić jednoznacznie ich kształt. Na rzucie poziomym miały rzut prostokąta, co mogłoby sugerować eliptyczną formę czaszy, ale na widoku elewacji sprawiają wrażenie okrągłych. Trudno przesądzić, czy wynikało to z ortodoksyjnego respektowania praw pespektywy, czy też z braku dostatecznych kompetencji młodego architekta. Niewielkie prezbiterium zostało ukazane z przekryciem w formie silnie spłaszczonej czaszy (lub wysokich faset), z wyciętymi trzema owalnymi oknami i zwieńczonej latarnią o specyficznym ,gruszkowatym” przekroju (il. 9).

Centralna forma korpusu i konieczność wyeksponowania głównego wejścia zdeterminowała formę frontu kościoła, który otrzymał kształt piętrowego, trójosio- 
wego portyku. Na skrajach został ujęty parami kolumn i przylegających do filarów oraz zwieńczony przerwanym tympanonem. W ten sposób na dole architekt uzyskał otwartą przestrzeń w portyku na dole i na górze. Frontalność głównej elewacji z portykiem została podkreślona parami kolumn umieszczonymi na ryzalitach bocznych obu kondygnacji. Wysunięty do przodu portyk został połączony lekko wklęsłymi ścianami, z lekko cofniętymi, kolumnowymi ryzalitami bocznymi. Portale elewacji frontowej Reisner opracował w formie profilowanych ram, ze zróżnicowanymi kształtami naczółków. Główny, prowadzący do kruchty, wieńczy odcinkowy naczółek wsparty na wolutowych konsolach. Na nim dwa putta podtrzymują kardynalski kartusz herbowy z trzema pszczołami Barberinich (il. 10). Nowocześniejsze stylistycznie są oprawy wejść bocznych, ozdobione przerwanymi naczółkami zakończonymi wolutami zbiegającymi się w muszli, a nad nimi putta podtrzymujące wieńce (il. 11). Zewnętrzne obramienia okien tamburu zostały opracowane w formie edikul z jońskimi półkolumnami. W naczółkach znajdują się popiersia świętych w otoczeniu liści palmowych.

Na przekroju podłużnym projektowanego kościoła widoczna jest ażurowa wieżyczka, nakryta dzwonowatym hełmem i zwieńczona dekoracyjnym szczytem w formie esowatych herm z główkami aniołków (il. 12). Okrągłe schody między prezbiterium a boczną kaplicą wskazywałyby na takie jej położenie. Można przypuszczać, że druga wieżyczka znajdowała się symetrycznie po drugiej stronie prezbiterium, gdzie również występują okrągłe schody. Charakterystyczną cechą projektu Reisnera jest zaproponowanie bogatego programu rzeźbiarskiego w postaci figur ustawionych na attyce tamburu oraz nad kaplicami.

\section{4. ŹRÓDŁA INSPIRACJI ARCHITEKTONICZNYCH REISNERA}

Kompozycja brył i kształt głównego korpusu kościoła zaprojektowanego przez Reisnera, składającego się z cylindrycznej bryły z kopułą na wysokim tamburze oraz wieńcem niższych kaplic, wpisują się w tradycję architektoniczną o antycznej genezie. Określiły ją Panteon, czyli S. Maria della Rotonda (125 r. po Ch.), oraz Muzoleum Konstancji, czyli Santa Contanza (IV w. po Ch.). Nowożytną redakcję tego modelu otworzył Andrea Palladio, projektując Tempietto Barbaro w Maser z 1580 r. W XVII w. do Panteonu jako wzoru nawiązał Bernini, projektując S. Maria della Assunzione w Ariccia (1662-1664). Budowlami tymi inspirował się Charles Errard, gdy wznosił kościół Notre-Dame-de-l’Assomption (1670-1676) w Paryżu (il. 13, 14). Powstał okrągły korpus z płytkimi wnękami ołtarzowymi i klasyczny portyk, ale nowością było dodanie wysokiego tamburu, co w konsekwencji silnie zmonumentalizowało bryłę i podkreśliło wertykalizm wnętrza. 
Poszukując genezy architektury młodego Reisnera, należy zwrócić uwagę na projekty Fontany, w tym czasie współpracownika Berniniego i Rainaldiego, ale wyrastającego na czołowego architekta Rzymu. Ideę adaptacji Koloseum na miejsce kultu Świętych Męczenników podjął Klemens X w związku z obchodami Roku Świętego w 1675 r. (Hager 319-337; Wegerhoff 164-169), a powrócił do niej Innocenty XI. Fontana zaproponował w środku amfiteatru Flawiusza wzniesienie kościoła $\mathrm{w}$ formie antykizowanej rotundy, $\mathrm{z}$ kopułą na wysokim tamburze i wieńcem kaplic wokół. Arena miała otrzymać formę owalnego placu, otoczonego podcieniami mieszczącymi Drogę Krzyżową (il. 15, 16). Choć pomysłu nie zrealizowano, to był on znany w środowisku rzymskich architektów, co potwierdza późniejsze wydanie rycin wykonanych przez Domenica Franceschiniego w L'Anfiteatro Flavio, descritto e delineato dal cavaliere Carlo Fontana z 1725 r. (L'Anfiteatro Flavio. Ryciny wykonał Domenico Franceschini). Równie istotny był projekt Fontany centralnego kościoła w baskijskiej Loyoli (Santuario di S. Ignazio a Loyola). Powstanie kompleksu kościelno-zakonnego zainicjowali w 1681 r. królowa Marianna Austriacka (Habsburg), wdowa po królu Hiszpanii Filipie IV, wraz z generałem zakonu jezuitów Giovannim P. Olivą. W tym wypadku również Fontana wykorzystał w projekcie ten sam model centralnej, kopułowej świątyni w formie rotundy z wysokim tamburem. Nowością zwiastującą nadchodzący późnobarokowy eklektyzm jest trójprzelotowy portyk o wybrzuszonej linii zewnętrznej, powtarzający linię korpusu. Długi czas budowy, jaki upłynął od jej rozpoczęcia w 1688 r., sprawił, że na klarowne, klasycyzujące formy Fontany nałożono bogatą, ornamentalną dekorację (il. 17).

Projekt Reisnera wykazuje wyraźne pokrewieństwa z projektami Fontany, zwłaszcza dla Koloseum: z dwustrefową, pilastrową artykulacją wnętrza, z szerokim pasem cokołu tamburu z wpisanymi płycinami ze scenami figuralnymi. Również uwzględnienie dwóch wieżyczek nadbudowanych przy prezbiterium spełniało obowiązujące dezyderaty zarówno we wcześniejszym konkursie architektonicznym z 1677 r., jak i w projektach Fontany.

We wnętrzu Reisner zastosował układ porządków zgodnie z powszechną, wręcz obowiązującą zasadą rzymskiej teorii i praktyki architektonicznej 2. poł. XVII w. - na dole koryncki, wyżej, uznawany za najgodniejszy, bo genetycznie rzymski - kompozytowy. Joński, jako niższej rangi w decorum, występuje w edikulach opraw okien.

W kopule naszkicował dość wyraźnie kompozycję freskową, prawdopodobnie Stracenie aniołów. Niewątpliwie wpłynęła na to malarska profesja artysty, ale można widzieć $\mathrm{w}$ tym inspiracje projektami z wcześniejszych konkursów akademickich, które Polak musiał znać, bo odbywały się, gdy był już w Rzymie. W 1677 r. Simon Chupin (Simone Sciupagna) narysował na zwycięskim projekcie dekorację w kopule (il. 18) (Guidoboni 196). Na zwycięskim projekcie w konkursie z soggeto Chiesa con due Campanilli $\mathrm{w} 1679$ r. Domenico Martinelli również naszkicował 
freski w hemisferycznej kopule (Lorenz 8-9, il. 6, s. 206-209, il. 195,197; Mossakowski 341-355). Sposób dekoracji w postaci fresku na kopule był w tym czasie dość anachroniczny, skoro większość kopuł sklepionych kościołów centralnych tej epoki pokrywano dekoracyjnymi, listwowymi żebrami i kasetonami. Można to thumaczyć programowym odrzuceniem stylistyki dojrzałego baroku rzymskiego na rzecz ujawniania związków z architekturą renesansową i antyczną, co było głównym dezyderatem ówczesnej polityki architektonicznej Akademii.

Kompozycja fasady odzwierciedla początki procesu kształtowania się - w 2. poł. XVII w., w Rzymie - nowego modelu sakralnych elewacji, łączącego tradycję klasyczną i klasycyzującą (antyk, renesans, wczesny barok) z dojrzałym barokiem, reprezentowanym przez czterech wybitnych architektów rzymskiego baroku. Do pierwszej tradycji nawiązuje stabilna optycznie, centralna część, ukształtowana przez pełnoplastyczne kolumny ustawione na dwóch kondygnacjach. Reisner nie dostawił jednak do centralnego korpusu klasycystycznego portyku w wersji znanej z Panteonu, jak to powszechnie nie tylko zalecano w konkursach akademickich, lecz także stosowano w praktyce architektonicznej, o czym świadczą dwa centralne kościoły przy Piazza del Popolo: S. Maria di Montesanto (Rainaldi, Bernini: 16621679) i S. Maria dei Miracoli (Fontana, 1675-1681). W układzie i plastyce elewacji można doszukiwać się refleksów kolumnowych fasad baroku, tak powszechnych w różnych wariantach w dziełach da Cortony, Borrominiego i Rainaldiego. Świeżo ukończone były wspaniałe, kolumnowe fasady według projektów Rainaldiego: S. Andrea della Valle (1656/1662-1665/1666) i S. Maria in Campitelli (projekt, 1658-1662; realizacja, 1663-1667) oraz Borrominiego San Carlo alle Quatro Fontane (1667-1677).

Front kościoła współtworzą skośnie dodane ryzality boczne w postaci par kolumn powtórzonych na obu kondygnacjach i zintegrowanych z centralnym portykiem lekko wklęsłymi odcinkami ścian. Rekonstruując proces projektowy Reisnera, można powiedzieć, że z wyjściowego schematu wieloosiowej elewacji kolumnowej odsunięte i cofnięte zostały skrajne przęsła. Zachowano wrażenie okazałej fasady kolumnowej, z górującą nad nim kopułą. Trudno - ze względu na skromny zakres wklęsłości fragmentów ścian - sformułować wniosek, czy było to świadome nawiązanie do pomysłów Borrominiego - a byłby to jeden z wcześniejszych przykładów recepcji form tego architekta nawet na gruncie rzymskim. Podobnie jak we wnętrzu, uwzględnił on gradację ważności porządków - niżej kapitele korynckie, wyżej kompozytowe, a jońskie w edikulach opraw okien.

W prezentowanym projekcie Reisnera znajdujemy aplikacje dekoracji architektonicznej zaczerpnięte $\mathrm{z}$ architektury dojrzałego baroku rzymskiego, ale indywidualnie zinterpretowane. Aniołki podtrzymujące girlandy na cokołach attyki tamburu są 
ewidentnie wzorowane na dekoracji z dwóch kościołów Berniniego: S. Maria della Assunzione w Ariccia (1662-1664) i S. Andrea al Quirinale (1658-1670).

Oryginalnością formy wyróżniają się obramienia okien wewnątrz tamburu. Reisner dokonał kompilacji wczesnobarokowych, plastycznych edikul o jońskich półkolumnach i trójkątnych naczółkach z przerwanym belkowaniem z wykrojem w postaci archiwolty, przerwanej zwornikiem z końcówkami zakończonymi ślimacznicami (il. 19). Formę tę, wywodzącą się z późnego manieryzmu, wykorzystywali architekci dojrzałego baroku. Przerwanymi archiwoltami zakończonymi wolutami Bernini zamknął podłucza empor z rzeźbami rodziny Cornaro w kaplicy tego rodu mieszczącej rzeźbę Ekstaza św. Teresy (1647-1652). Zapewne pod wpływem tego artysty przerwana archiwolta rozpowszechniła się w późnobarokowej architekturze eklektycznej, choć pojawiało się ona wcześniej, choćby w portalu kościoła S. Andrea e S. Silva al Celio [1607-1608] projektu Flamminio Ponzio (Veragnoli 115). Występuje w przelocie łuku triumfalnego poświęconego Klemensowi XI, z 1701 r., według projektu Carla Fontany (Coudenhove-Erthal il. 35) oraz w drezdeńskim Hofkirche (1739-1755) Gaetano Chiaveriego (Hempel i Krönert; Caraffa). Główni monografiści archichtekta nie podjęli tematu genezy formy podłucza. Pojawił się on również w warszawskim kościele Kamedułów (konsekracja: 1758) (Guttmejer 127).

Do repertuaru dojrzałego baroku należą również oprawy okienne elewacji frontowej piętra w postaci przerwanego belkowania i z naczółkiem formie odcinków zakończonych wolutkami. Z projektu wynika, że prezbiterium miało być założone na lekko wydłużonym prostokącie o zaokrąglonych narożach i nakryte sufitem $\mathrm{z}$ fasetami, w przekroju podobnym do spłaszczonej mocno kopuły. Zbliża się ona do rozwiązań stosowanych przez Borrominiego w Collegio di Propaganda Fide i Oratorium Filipinów. Widoczne są trzy owalne okna dekorowane łuczkami o zarysie litery „C” i z żebrami wychodzącymi z wolut podstawy kopuły, które należały do charakterystycznych motywów da Cortony, przejętych od Michała Anioła. Wieńcząca latarnia otrzymała oryginalny kształt - w przekroju kontur gruszki, z trzema oknami o takim samym kształcie, ujęty rozciągniętymi esowato wolutami, należącymi do kanonicznych motywów stosowanych za da Cortoną przez rzesze architektów późnobarokowego eklektyzmu.

W opracowaniu hemisferycznej czaszy Reisner pozostał wierny konwencji stosowanej w nieomal wszystkich ówczesnych projektach budowli centralnych opartych na rzucie koła lub regularnego wieloboku, włącznie z półkolistym profilem zewnętrznych żeber, łączących się esownicami z podstawą latarni. Finezyjnie została opracowana forma latarni z obiegającymi kolumienkami, łączącymi się w pary tworzące edikulowe oprawy okien i zwieńczone odcinkami zakończonymi wolutami. Latarnie otoczone zostały wolutami o silnie wydłużonych spływach (il. 20) (Villani 123-135). 
Podsumowując należy stwierdzić, że projekt Reisnera odzwierciedlał specyficzne tendencje w architekturze lat sześćdziesiątych i siedemdziesiątych XVII w., zwłaszcza w edukacji architektonicznej Akademii św. Łukasza. Próbowano tam pogodzić klasycyzujące tendencje propagowane przez dwór francuski z nawiązywaniem do form dojrzałego baroku rzymskiego. W konsekwencji próby połączenia cech dwóch tradycji powstało dzieło eklektyczne, tak jak i inne projekty konkursowe tworzone przez studentów Akademii św. Łukasza.

\section{POLITYCZNE TŁO}

KSZTAŁTOWANIA SIĘ KONCEPCJI ARCHITEKTURY SAKRALNEJ W KRĘGU AKADEMII ŚW. ŁUKASZA W LATACH 1664-1683

Pozornie nietypowe procedury przyznawania wyróżnień Polakom, jak również koncepcja architektoniczna projektu Reisnera stają się zrozumiałe, gdy spojrzymy na nie w kontekście procesów politycznych zachodzących w Europie w latach 16641683, których stronami byli król Francji Ludwik XIV, cesarz Leopold I, papież Innocenty XI oraz król Polski Jan III. Przypomnijmy jedyne w syntetycznym zarysie węzłowe zagadnienia historyczne, lecz wyjaśniające skomplikowane mechanizmy politycznych uwikłań sztuki 2. poł. XVII w.

W 1664 r. został zawarty w Pizie traktat między Ludwikiem XIV i papieżem Aleksandrem VII (zm. 1667). Wygaszał on kilkuletni konflikt między Stolicą Apostolską a królem Francji. Jedną z przyczyn konfliktu było żądanie uzyskania przez Ludwika XIV prawa do zatwierdzania biskupów, które Watykan odrzucił. W odpowiedzi król poparł pretensje rodów d'Este i Farnese do terytoriów Państwa Kościelnego, zajął papieskie dobra w Awinionie i oskarżył gwardię papieską o napaść na ambasadora Francji.

Traktat w Pizie uznawał żądania króla francuskiego. Znalazło się tam - szczególnie ważne dla europejskich spraw artystycznych - zastrzeżenie, że król francuski ma prawo korzystać z usług artystów papieża, z czego niezwłocznie skorzystał. W kwietniu 1664 r. agent francuski Elpidio Benedetti zaprezentował w Rzymie rysunki i projekty Luwru autorstwa Louis'a Le Vau trzem architektom: Rainaldiemu, da Cortonie i Berniniemu. Wykonali oni wstępne projekty. Do Paryża zaproszony został Bernini, którego pobyt w Paryżu trwał pięć miesięcy, od czerwca do października 1665 r., ale współpraca z dworem wersalskim trwała również później, już po jego powrocie do Rzymu. Powstały cztery projekty Luwru, niezrealizowane, ale istotnie wpływające na kształt nowej architektury we Francji. Akcja ta stanowiła tylko część działań Ludwika XIV i jego dworu, z ministrem Jean-Baptist Colbertem na czele. Celem było stworzenie nowej formuły sztuki francuskiej, odzwierciedlającej potrzeby absolutyzmu 
(Montanari 117-138). Najpierw jednak należało wypracować ją w niekwestionowanym centrum artystycznym i uzyskać rzymską legitymizację. W 1666 r. Colbert przy pomocy Charles'a Le Bruna i pod patronatem Berniniego założył w Rzymie Akademię Francuską (Académie de France), a jej dyrekcję objął architekt Charles Errard (1666-1672, 1675-1684). Prócz sześciu malarzy i sześciu rzeźbiarzy stypendia otrzymywali także dwaj architekci. Do ich zadań należało inwentaryzowanie starożytnych i współczesnych zabytków Rzymu, wykonywanie kopii malarstwa i rzeźby oraz dokonywanie zakupów dzieł (Guidoboni 53-64). Edukację na miejscu, w Paryżu, miała zapewnić powołana 1671 r. Królewska Akademia Architektury (Académie Royale d'architecture) pod kierownictwem François'a Blondela.

Istotnym elementem polityki artystycznej Francuzów było dążenie do przejęcia kontroli nad Akademią św. Łukasza, co nasiliło się za rządów papieży Klemensa IX (1667-1670) i Klemensa X (1670-1676), próbujących układać się z ekspansjonistycznym politycznie i kulturowo Ludwikiem XIV. Profrancuska orientacja w Rzymie miała wsparcie w Barberinich, z kardynałami Francesco (zm. 1679) i Antoniem (zm. 1671). Ich związki z Francją zacieśniły się w 1644 r., gdy musieli opuścić Rzym, a schronienia w Paryżu udzielił im kardynał Mazarini. Po ułaskawieniu przez Innocentego $\mathrm{X}$ wrócili oni do Włoch, ale pozostawali w przyjaznych relacjach politycznych i personalnych z Ludwikiem XIV, co okazało się korzystne, gdy ten zaczął dominować nad papiestwem. Wpływową postacią Kurii Rzymskiej był również Camillo Massimi (zm. 1677), który wsparciu Francji zawdzięczał kapelusz kardynalski, otrzymany w $1670 \mathrm{r}$.

Walcząc o dominację nad papieżem, Ludwik XIV zaczął wykorzystywać uczelnię jako jeden z elementów polityki artystycznej (Smith, Architectural Diplomacy 25-50; Metzger Habel). Do 1679 r. protektorem Akademii z ramienia papieża - jak już wspomniano - był Francesco Barberini, stronnik Francji, co skutkowało mianowaniem na principe Francuzów - Charles'a Errarda $(1672,1678)$ i Charles'a Le Bruna (1676-1677), który przebywając w Paryżu obowiązki powierzył Errardowi. Akademia stała się areną ścierania się dwóch koncepcji architektury sakralnej (Cipriani 351-352). Z jednej strony rozwijano i interpretowano formy dojrzałego baroku rzymskiego ukształtowane przez da Cortonę, Borrominiego, Berniniego i Rainaldiego, propagowane przez uczniów, zwłaszcza przez Fontanę. Francuskie koncepcje zmierzały do przyjęcia budowli centralnych za podstawę studiów - antyczne (Panteon, Mauzoleum Konstancji) oraz renesansowe (m.in. Bazylika św. Piotra z fazy Michała Anioła). Te ostatnie, wraz z powrotem do tradycji klasycznej jako podstawy tworzenia architektury, miały zwolenników wśród Włochów, pełniących funkcje „,prezydentów” Akademii - malarza Carlo Marattę (1664-1665), architekta Mattia de Rossiego (1681), którym przewodził wybitny teoretyk klasycyzmu Gian P. Bellori, również związany jako wykładowca z uczelnią rzymską. 
W Akademii - silnie podporządkowanej Francuzom - jedną z metod budowania prestiżu i znaczenia artystów francuskich było organizowanie konkursów artystycznych dla studentów malarstwa, rzeźby i architektury, z jednoczesnym wpływaniem na przyznawanie nagród. Rozstrzygnięty w 1673 r. konkurs malarski, faktycznie przygotowany rok wcześniej przez Errarda, przyniósł sukces Francuzom - otrzymali aż pięć nagród (Hager 118-119). Wzbudziło to uznanie Colberta, zalecającego dyrektorowi kontynuowanie przyjętej strategii edukacji i promowania rodzimych artystów. Podobnie pełnym ,sukcesem” Francuzów zakończył się konkurs architektoniczny ogłoszony w 1677 r., gdy principe był Le Brun, a w jego imieniu rządził i sogetto na Chiesa a pianta centrale zainicjował Errard (Smith, "The «Concorso Accademico»"). Brali w tym udział - jak przypuszcza Francesco Guidoboni - profesorowie Akademii św. Łukasza: Tommasini, Fontana, Felice della Greca i de Rossi oraz sekretarz Ghezzi. W warunkach określono, że kościół powinien mieć plan oktogonalny, z kopułą, klasycznym portykiem i dwoma wieżami. Trzy główne nagrody w pierwszej klasie architektury otrzymali Francuzi: Simon Chupin (Simone Sciupagna), Augustin-Charles d'Aviler (Agostino Davilier), Claude Desgots (Claudio Desgot).

W pewnym momencie relacje polityczne papiesko-francuskie ulegają zmianie. Papież Innocenty XI od początku swojego pontyfikatu, rozpoczętego w 1676 r., podjął próby powstrzymywania hegemonistycznej polityki króla Francji, co doprowadziło w latach 1681-1682 do eskalacji konfliktu, mającego początki jeszcze w decyzji Ludwika XIV z 10 lutego 1673 r., gdy rozszerzył on droit de régale na kilka prowincji francuskich - Langwedocję, Guyenne, Prowansję i Dauphiné. Równało się to z przejęciem kontroli nad majątkami i nominacjami kościelnymi. Mimo prób papieża nakłonienia go do odstąpienia od tej decyzji, 19 marca $1682 \mathrm{r}$. francuskie zgromadzenie duchowieństwa (Assemblée du clergé) poparło króla. W retorsji z 11 kwietnia 1682 r. papież unieważnił uchwalone artykuły i zawiesił nominacje kardynalskie i biskupie biorącym udział w posiedzeniu. W tych latach Ludwik XIV dokonał aneksji kilku prowincji, będących formalnie w granicach Cesarstwa, w ramach polityki „ponownego zjednoczenia” (politique des Réunions).

Eskalacja konfliktu Innocentego XI z Ludwikiem XIV ujawniła się również w polityce wobec Akademii, mającej na celu eliminację wpływów francuskich i możliwości wykorzystania jej do własnych celów, zwłaszcza antyfrancuskich. Wpływ na Akademię Innocenty XI wywierał za pośrednictwem kardynałów, których łączyły z uczelnią różne relacje formalne i nieformalne, wpływających na obsadzanie stanowisk principe i członków ,zarządu” Akademii św. Łukasza. Do najważniejszych należał Carlo Barberini, od 1679 r. protektor Akademii. W przeciwieństwie do stryja Francesca, dystansował się od związków z Francją, a swoją karierę wiązał z urzędującym papieżem. Zręczny dyplomata, pełnił funkcje 
najpierw kardynała protektora Księstwa Sabaudzkiego (od 1671 r.), potem katolickich kantonów Szwajcarii (od 1680). Realny wpływ na edukację studentów mieli też inni kardynałowie, którzy pełnili rolę protektorów wyróżniających się lub mających wpływowych mecenasów adeptów. Przewijający się, o czym była już mowa wcześniej, kardynałowie - Odescalchi, Azzolini czy Carpegna - zdecydowanie należeli do opcji propapieskiej. Lata 1681 i 1682, gdy polscy studenci wyróżniani są zaszczytami, to czas przesilenia politycznego, gdy dokonuje się zasadnicza zmiana w wyborach principe. Środowisko profrancuskie jest odsuwane, jak jeden z jego przedstawicieli de Rossi (1681), a stanowiska principe obejmują artyści ściśle związani z papieżem - Luigi Garzi (1682), Giovanni B. Contini (1683) oraz Fontana (1686). Lojalność Garziego, od 1680 r. członka i prezydenta Congregazione dei Virtuosi al Pantheon, prestiżowego stowarzyszenia malarzy całkowicie podporządkowanego papieżowi, nie budziła wątpliwości.

Zaostrzenie relacji papiesko-francuskich i cesarsko-francuskich zbiegło się ze zmianą polityki Jana III, polegającej na odejściu od polityki profrancuskiej (od 1679) na rzecz zbliżenia polsko-austriackiego i wsparcia papieża Innocentego XI. Początkowo antagonizm wynikał z zawiedzionych nadziei króla na wsparcie Ludwika XIV w konflikcie z elektorem brandenburskim. Jednak niebawem wspólnym interesem cesarstwa, papiestwa i Polski stało się stawienie czoła zagrożeniu tureckiemu.

Jak już wcześniej przedstawiono, zabiegi wpływowych dostojników Kurii Rzymskiej o prestiżowe wyróżnianie polskich studentów - jak pierwsze nagrody w konkursach, nadanie tytułów szlacheckich, wreszcie przyjęcie ich na członków Akademii - nie należały do typowych działań, a przeciwnie, miały charakter wyjątkowy i precedensowy. Intensyfikacja przyznawania zaszczytów przez władze uczelni, a także protektorów Barberiniego i Odescalchiego wobec polskich studentów przypadła na 2 połowę roku 1681 i 1682, gdy intensywnie tworzono przymierze polsko-austriackie, trwały pertraktacje o finansowanie kampanii wojennej Sobieskiego przez papieża, a wpływy Ludwika XIV, sprzymierzeńca Turcji, radykalnie eliminowano w Rzymie. Nie wydaje się, ażeby ta korelacja czasowa była przypadkowa. Ewidentnie była ona powiązana $\mathrm{z}$ rozgrywającymi się w tle pertraktacjami politycznymi, a życzliwy stosunek wobec królewskich stypendystów miał jakiś określony cel. Nawet - niespotykana wcześniej - zmiana procedur konkursu w 1681 / 1682 została dokonana w taki sposób, że korzystnie wpłynęła na wybór laureatów. Ich promocja była nie tylko znaczącym gestem wobec Jana III, ale dodatkowo miała charakter zdecydowanie antyfrancuski.

Zakres tych protekcji upoważnia do sformułowania tezy, że obecność obu stypendystów w Rzymie była dla Jana III szczególnie ważna, co wynikało nie tylko z zamiłowania króla do malarstwa. Istniały też inne przyczyny. Polacy byli nie tylko zdolnymi artystami, lecz także oddanymi i inteligentnymi członkami dworu; 
znali języki włoski, niemiecki i łacinę, może również inne, mniej znaczące, jak ruski czy ormiański. Mało prawdopodobne, aby posługiwali się francuskim, ale nie można tego wykluczyć. Faktycznie byli w jakimś stopniu artystami-dworzanami królewskimi. Ze znajomością świetnych manier ceremoniału zapoznali się zapewne na dworze Sobieskiego, a jako ambitni i zdolni studenci mogli szybko przyswoić w Rzymie elitarne wzorce zachowań i konwencji. Jednej z okazji dostarczył Reisnerowi udział w organizacji niektórych wydarzeń podczas radziwiłłowskiego poselstwa z obediencją. Po powrocie do Polski obaj artyści otwarcie manifestowali wysoki status, co znalazło odzwierciedlenie w portrecie Reinera umieszczonym na epitafium oraz na portrecie Siemiginowskiego. Ukazani zostali bowiem w strojach cudzoziemskich, elitarnych, a nie w sarmackiej konwencji portretowej (Karpowicz, „Autoportret Siemiginowskiego" 139-144).

W świetle tych faktów i spostrzeżeń należy postawić pytanie, czym poza studiowaniem sztuki zajmowali się Polacy? Nieodparcie nasuwa się skojarzenie o jakiejś roli artystów w nieformalnych działaniach dyplomatycznych. Mógł to być transfer niejawnych informacji, opinii, nastrojów lub cennych plotek na dwór królewski. Zdawali sobie z tego sprawę watykańscy kardynałowie protektorzy, u których Barberini zabiegał o intratne finansowo stanowisko protektora Polski (protettore del regno) i co udało mu się osiągnąc w 1681 r. (Platania, „La nomina di Carlo Barberini” 215-224; Platania, „Carlo Barberini” 75-120).

\section{ARTYSTA-DWORZANIN:}

\section{EDUKACJA REISNERA A POLITYKA ARTYSTYCZNA KRÓLA JANA III}

Niezależnie od wypełnienia przypuszczalnych zadań polityczno-dyplomatycznych, może nawet wywiadowczych, głównym celem pobytu Polaków była edukacja artystyczna. Wysłanie Reisnera i Siemiginowskiego na studia do Rzymu wiązało się ze znacznymi kosztami, które Jan III musiał wyłożyć na podróż, kilkuletni pobyt, materiały artystyczne, oraz zapewnieniem protekcji wysokich dostojników kościelnych związanych z Watykanem i uczelnią. Kompleksowa, mecenasowska opieka nad artystami - od edukacji po stałe zatrudnienie na dworze - nie zaistniały wcześniej w Rzeczypospolitej. Precedens stanowiła również malarska specjalizacja, w jakiej mieli się edukować Reisner i Siemiginowski, nie należąca w odbiorze społecznym w naszym kraju do prestiżowej dziedziny sztuki, w przeciwieństwie do architektury civilis i militaris.

Utrwalona powszechnie wśród badaczy opinia, że król, inicjując wykształcenie wysokiej klasy malarzy, pragnął przede wszystkim zapewnić realizację artystycznych potrzeb dworu, jest uzasadniona, ale wymaga szerszego spojrzenia. Czas 
skierowania adeptów malarstwa na studia zbiega się z zakupem w 1677 r. Wilanowa i intensywną rozbudową pałacu przez Augustyna Locciego młodszego. Wnętrza, podobnie jak i innych pałaców i dworów - w Żółkwi, Jaworowie, Kukizowie czy Marymoncie, wkrótce miały być wypełnione dekoracjami malarskimi (Starzyński, „Wilanów. Dzieje budowy” 4-70). Praktyka artystyczna Reisnera i Siemiginowskiego po powrocie do Polski potwierdza jednoznacznie, że cel ten został osiągnięty.

$\mathrm{Na}$ decyzje Sobieskiego należy spojrzeć z szerzej perspektywy, jaką była polityka budowania wizerunku króla aspirującego do elity władców europejskich. Kluczowa wydaje się propagandowa funkcja obrazów, zwłaszcza powielanych w formie graficznej. Król zdawał sobie w pełni sprawę z perswazyjnej siły tych mediów, sprawdzonych przez najważniejszych ówcześnie władców - Ludwika XIV, cesarza Leopolda I czy papieży. Dowiódł tego w następnych latach po wiktorii wiedeńskiej, rozpowszechniając dziesiątki ilustracji ukazujących swoją osobę i odnoszone sukcesy militarne. Aby zrealizować zamiary propagandowe, niezbędne było stworzenie dworskiego środowiska artystycznego, dyspozycyjnego w wykonywaniu zamówień.

Z przebiegu nauki i późniejszej aktywności Polaków wynika, że od początku młodzi adepci sztuki zostali zobowiązani przez króla do kontynuacji nauki malarstwa (sztalugowego i freskowego), a dodatkowo każdy z nich miał się zapoznać z innymi dyscyplinami: Siemiginowski - z grafiką, Reisner $-\mathrm{z}$ architekturą i geodezją-miernictwem ${ }^{10}$. W przeciwieństwie do licznej w Warszawie grupy architektów, i dostępnych w Gdańsku rzeźbiarzy mogących zaspokoić potrzeby fundacyjne monarchy, malarstwo w latach 70. XVII w. reprezentowali wiekowi Daniel Schultz (zm. 1683), Andreas Stech (zm. 1697), Claude Callot (zm. 1687) i Jan Trycjusz (Tricjusz) (zm. po 1699) oraz malarze prezentujący rzemieślniczy poziom.

Instytucjami kształcącymi artystów w tym czasie na Zachodzie były „Akademie", ściśle powiązane z patronatem władców i kształcące artystów wykorzystywanych do realizacji dworskich potrzeb artystycznych. Pod zwierzchnictwem papieży funkcjonowała rzymska Akademia św. Łukasza. Ludwikowi XIV podlegały paryskie Królewska Akademia Malarstwa i Rzeźby (Académie Royale de peinture et de sculpture, od 1648) i Królewska Akademia Architektury (Académie Royale d'architecture, od 1671) oraz rzymska Akademia Francuska (Académie de France, od 1666). Idea powoływania innych uczelni artystycznych, nieomal jako atrybutu prestiżu władcy europejskiego, rozwinęła się właśnie w czasach panowania So-

10 Jeszcze w Rzymie Siemiginowski wykonał sześć sztychów na podstawie fresków Lazzaro Baldiego znajdujących się w Palazzo Odescalchi (Karpowicz, „O Janie Reisnerze” 21). Wyróżniającym przykładem twórczości graficznej tego artysty w Polsce są ryciny do Flores Vitae B. Salomae... ks. Sebastiana Piskorskiego (Ostrowski 43-52; Kurzej 82-112). 
bieskiego. Powstała wtedy Academie der Mahl-, Bild- und Baukunst (od 1696), założona przez elektora brandenburskiego Fryderyka III, późniejszego króla Prus Fryderyka $\mathrm{I}^{11}$, oraz akademia artystyczna w Wiedniu, utworzona przez Petera Strudla (od 1688), objęta następnie opieką cesarską.

W tym kontekście zwraca uwagę dyskusyjny, lecz nie pozbawiony podstaw pogląd, że wraz z inicjatywą kształcenia rodzimych artystów przyświecał królowi ambitniejszy cel - ukształtowanie instytucji (środowiska) na poziomie przewyższającym dominującą ówcześnie w Polsce rzemieślniczą i warsztatową praktykę edukacyjną, na wzór którejś z akademii europejskich. Hipotezę tę sformułowano na podstawie wzmianki zamieszczonej w dziele Jakuba K. Haura Skład abo skarbiec znakomitych sekretow oekonomiey ziemiańskiey ... z 1693 r. dedykowanym Sobieskiemu (Starzyński, „Dwór artystyczny” 149-151; Mańkowski 5-9; Karpowicz, „O Janie Reisnerze” 27-30; „Stypendyści królewscy” 109-114). Wychwalając monarchę za inicjatywy artystyczne, autor pisze, że w Wilanowie znajdują się ,szkoły”, w których powstają różne dzieła malarskie, i nie trzeba teraz sprowadzać z zagranicy obrazów i artystów (Haur 357) ${ }^{12}$. Zamykające akapit zdanie: ,aby się swojscy ludzie w tym konście ćwiczyli” mogłoby wskazywać, że prowadzono tam naukę malarstwa - oczywiście pod kierunkiem Siemiginowskiego i Reisnera. Ostatecznie aktywność artystów w Wilanowie, zarówno stypendystów, jak i pracujących później okazjonalnie, nie została ujęta $\mathrm{w}$ instytucjonalne ramy uczelni, a dwaj wybitni malarze budowali prestiż króla jako mecenasa, łącząc pracę artystyczną z innymi funkcjami dworskimi. Niemniej ich pozycja społeczna i dworska, jakkolwiek trudna do jednoznacznego zdefiniowania, była wysoka i zbliżona do statusu artystów-dworzan obecnych na królewskich i książęcych dworach. Na pełne docenienie wartości artysty w Polsce trzeba było poczekać sto lat - do czasów Stanisława Augusta i „Pierwszego Malarza Króla", Marcella Bacciarellego.

11 Jeden z kolegów polskich studentów, Michael Probener, pochodzący z Pomorza i uczący się w Akademii św. Łukasza, otrzymał nagrody w konkursie: w 1680 r. - drugą nagrodę w pierwszej klasie ex equo z Giuseppe Nicola Nassinim za Sąd Salomona, w 1681 r. - drugą nagrodę w pierwszej klasie za obraz Budowa wieży Babel (pierwszą otrzymał Siemiginowski). Probener od 1691 r. był malarzem nadwornym, a w 1701 r. - „dyrektorem” Akademie w Berlinie (por. Müller 80-81).

12 „W Wilanowie pod Warszawą z fundaciej i z pobożności osobliwej Najjaśniejszego Pana szczęśliwie nam panującego znajdują się teraz takie pomienione szkoły potrzebne, wygodne i chwalebne zkąd dopiero tęgi konsztu malarskiego wynikają w Polszcze arkana co to są sztylagi, proportie, perspektywy, lanczawty i dynensie (sic!) figur różnych, i sztuką przedniej inventiej, dawno tego potrzebowała Polska, dla chwały Bożej i dla ułatwienia kosztu, i trudności z cudzych krajów zaciągając coraz takich obrazów, jako też i mistrzów w podobnej potrzebie, gdy może teraz takich obrazów, jako też i mistrzów w podobnej potrzebie, gdy może być teraz, jak w domu swoją wygodą oraz i na sławę swego narodu, aby się swojscy ludzie w tym konście ćwiczyli”. 


\section{BIBLIOGRAFIA}

Billewicz, Teodor. Diariusz podróży po Europie w latach 1677-1676, z rękopisu odczytał, wstępem i komentarzem opatrzył Marek Kunicki-Goldfinger, Wydawnictwo Neriton, 2004.

BonacCorso, Giuseppe, Francesco MoschinI, a cura. Carlo Fontana 1638-1714 Celebrato Architteto. Convegno Internazionale, Roma, Palazzo Carpegna 22-24 ottobre 2014, Accademia Nazionale di San Lica, 2017.

CARAFFa, Constanza. Gaetano Chiavri (1689-1770) architetto romano della Hofkirche di Dresda. Silvana Editoriale, 2006.

Cipriani, Angela. „Die "Accademia di San Luca” in Rom“. Entwerfen Architektenausbildung in Europa von Vitruv bis Mitte des 20. Jahrhunderts Geschichte - Theorie - Praxis. Herausgegeben Ralph Johannes, Junius Verlag GmbH, 2009, ss. 344-358.

Corrispondenza del lucchese Tommaso Talenti segretario intimo del re di Polonia con Carlo Barberini protettore del regno (1681-1693), (Acta barberiniana, Nr 1), a cura di Gaetano Platania, Edizioni Sette Città, 2004.

Coudenhove-Erthal, Eduard. Carlo Fontana und die Architektur des römischen Spätbarocks. A. Schroll Verlag, 1930.

Duverger, Erik. „Le commerce d'art entre la Flandre et l'Europe Centrale au XVIIe siècle”. Evolution générale et développements régionaux en histoire de l'art, red. György Rózsa, t. 2, Akadémiai Kiadó Budapeszt, 1972.

Guidoboni, Francesco. „I primi concorsi accademici di archittetura tra Roma e la Francia, 1677. Concorso accademico 1677 prima classe". Roma-Parigi Accademie a confronto. L'Accademia di san Luca e gli artisti francesi XVII-XIX secolo, a cura di Carolina Brook, Elisa Camboni, Gian Paolo Consoli, Francesco Moschini, Susanna Pasquali, Accademia Nazionale di San Luca, 2016.

GutTmejer, Karol. „Kościół Kamedułów na Bielanach w Warszawie. Problem formy i autorstwa”. Kultura artystyczna Warszawy, red. Zbigniew Michalczyk i in., Wydawnictwo Neriton, 2010.

Habel, Dorothy Metzger. The Urban Development of Rome in the Age of Alexander VII. Cambridge University Press, 2002.

HAGER, Hellmutt. „Carlo Fontana's projekt for a church in honour of „Ecclesia Triumphans” in the Colossseum, Rome". Journal of the Warburg and Courtauld Institutes, vol. 36, 1973, ss. 319-337.

Hager, Hellmutt. „L'Accademia di San Luca e i concorsi di architettura”. Aequva potestas Le arti in gara a Roma nel Settecencto, a cura Angela Ciprani, Edizione de Luca, 2001, ss. 117-124.

HAUR, Jakub K. Sktad abo skarbiec znikomitych sekretow oekonomiey ziemianskiey... W Krakowie, 1693.

Hempel, Walter i Walter Krönert, Gaetano Chiaveri Der Architekt der katholischen Hofkirche zu Dresden. Hanau/M: Dausien, 1956.

JAroszuK, Jan. „Poselstwo z obiediencją Michała Kazimierza Radziwiłła do Rzymu w latach 16791680". Micellanea Historico-Archivistica, t. 3, 1989, s. 105-119.

KaRPowicz, Mariusz. Jerzy Eleuter Siemiginowski, malarz polskiego baroku. Zakład Narodowy im. Ossolińskich Wydawnictwo, 1974.

KARPOwicz, Mariusz. „Jan Reisner - zapomniany malarz i architekt”. Biuletyn Historii Sztuki, t. 21, 1959, ss. 70-83.

Karpowicz, Mariusz. „O Janie Reisnerze po raz wtóry”. Biuletyn Historii Sztuki, t. 36, 1974 , ss. 253-267.

Karpowicz, Mariusz. „Stypendyści królewscy w Rzymie”. Primus inter pares. Pierwszy wśród równych, czyli opowieść o królu Janie III, Wydawnictwo Muzeum Pałacu Króla Jana III w Wilanowie, 2013, ss. 109-113.

Krautheimer, Richard. The Rome of Alexander VII 1655-1667. Princeton University Press, 1985.

Kurzes, Michał. „Depingere fas est”. Sebastian Piskorski jako konceptor i prowizor. Imedius agencja reklamowa sp. z o.o., 2018. 
L'Anfiteatro Flavio descritto e delineato dal cavaliere Fontana, Carlo... Ryciny Domenico Franceschini, Haia [Haga, faktycznie Rzym], 1725.

L'Idéal classique. Les échanges artistiques entre Rome et Paris au temps du Bellori (1640-1700), a cura di Olivier Bonfait, Desmas Anne-Lise, Académie de France à Rome ed. Somogy, 2002.

Lorenz, Hellmut. Domenico Martinelli und die österreichische Barockarchitektur. Verlag der Österreichischen Akademie der Wissenschaften Wien, 1991.

Magnuson, Torgil. Rome in the Age of Bernini, vol. I, From the election of Sixtus V to the death of Urban VIII. Almoquist \& Wiksel International Stockholm, Sweden / Humanities Press N.J. U.S.A., 1982.

MaŃKowski, Tadeusz. „Szkoła malarska w Wilanowie za Jana III. Sprawozdanie Towarzystwa Naukowego Warszawskiego. Wydziat II, t. 43, 1950, ss. 5-9.

Marconi, Paolo, Angela Cipriani i Enrico Valeriani. I disegni di architettura dell'Archivio storico dell'Accademia di San Luca. De Luca Editore, 1974.

MontANARI, Tomaso. „Bellori e la politica artistica di Luigi XIV. L'Idéal classique. Les échanges artistiques entre Rome et Paris au temps du Bellori (1640-1700), a cura di Olivier Bonfait i Anne-Lise Desmas, Académie de France à Rome ed. Somogy, 2002, ss. 117-138.

Mossakowski, Stanisław. Recenzja Domenico Martinelli und die österreichische Barockarchitektur. Hellmut Lorenz. Verlag der Österreichischen Akademie der Wissenschaften Wien, 1991”. Biuletyn Historii Sztuki, t. 58, 1996, ss. 341-355.

MüLLER, Hans. Die Königliche Akademie der Künste zu Berlin 1696 bis 1896. Verlag von Rich, 1896.

Osiecka-Samsonowicz, Hanna. Polskie uroczystości w barokowym Rzymie 1587-1696. Instytut Sztuki PAN, 2012.

Ostrowski, Jan. „Flores Vitae B. Salomae, nieznany cykl graficzny Jerzego Eleutera Szymonowicza-Siemiginowskiego". Biuletyn Historii Sztuki, t. 35, 1973, s. 43-51.

PIETRZAK, Jan. „Siedemnastowieczna podróżniczka. Wrażenia Katarzyny z Sobieskich Radziwiłłowej z podróży po Europie Zachodniej w latach 1677-1678”. Kulturowe wzorce a spoteczna praktyka. Studia z dziejów kobiet, red. Agnieszka Jakuboszczak, Przemysław Matusik, Instytut Historii Uniwersytetu im. Adama Mickiewicza, 2012, ss. 103-126.

Platania, Gaetano. „La nomina di Carlo Barberini protettore di Polonia (1681) in alcune lettere inedite conservate nel fondo barberiniano della Biblioteca Vaticana". Per sovrana risoluzione». Studi in ricordo di Amelio Tagliaferri. Arte Documento. Rivista di Storia e tutela dei Beni Culturali. Quaderni, vol. 4, 1998, pp. 215-224.

Polonia e curia romana. Corrispondenza di Maria Kazimiera Sobieska regina di Polonia, con Carlo Barberini protettore del regno (1681-1699) e il soggiorno romano di una famiglia polacca in esilio, (Acta barberiniana, Nr 3), a cura Gaetano Platania, Edizioni Sette Città, 2016.

Polonia e curia romana. Corrispondenza tra Giovanni III Sobieski, re di Polonia con Carlo Barberini protettore del regno (1681-1696), (Acta barberiniana, Nr 2), a cura Gaetano Platania, Edizioni Sette Città, 2011.

„Probener Michael”. Allgemeines Lexicon der bildenden Künstler von Antike bis zur Gegenwart..., Band 27, Verlag von E.A. Seemann, 1933, s. 410.

RastawieCKI, Edward. Słownik malarzów polskich tudzież w Polsce osiadtych lub czasowo w niej przebywajacych, t. 2. Nakładem autora, 1851.

„Reisner Jan (Ratzner, Reizner, Rejnert, Rejsner, Rejzner, Reyzner, Rezner, Rysler, Ryzner)”. Słownik architektów i budowniczych środowiska warszawskiego XV-XVIII wieku, red. Paweł Migasiewicz, Hanna Osiecka-Samsonowicz, Jakub Sito, Instytut Sztuki PAN, 2016, ss. 382-384.

Roma-Parigi Accademia a confronto L'Accademia di San Luca e gli artisti francesi XVII-XIX secolo, a cura Carolina Brook, Elisa Camboni, Gian Paolo Consoli, Francesco Moschini, Susanna Pasquali, Accademia Nazionale di San Luca, 2016.

Stownik architektów i budowniczych środowiska warszawskiego XV-XVIII wieku, red. Paweł Migasiewicz, Hanna Osiecka-Samsonowicz, Jakub Sito, Instytut Sztuki PAN, 2016. 
SмITH, Gil R. „The «Concorso Accademico» of 1677 at the Accademia di San Luca”. Projects and Monuments in the Period of The Roman Baroque, edited by Hellmut Hager, Susan Scott Munshower, Pensylvania State University, vol. 1, 1984, ss. 27-45.

Smith, Gil R. Architectural Diplomacy. Rome and Paris in the Late Baroque. The MIT Pres Cambridge (Mass.) and London, 1993.

STARZYŃSKI, Juliusz. „Dwór artystyczny Jana III”. Życie Sztuki, t. 1, 1934, ss. 137-156.

StARZYŃSKI, Juljusz. Wilanów dzieje budowy pałacu z Jana III. Zakład Architektury Polskiej i Historji Sztuki Politechniki Warszawskiej, 1933.

Theatrum Europeum der Beschreibung der Denckwürdigsten Geschichten in Europa vom Jahr 1672 bis 1679. Matthäus Merian (d.Ä.), Bd. 11, Franckfurt am Meyn 1682.

Veragnol, Claudio. S. Croce in Gerusaleme. La basilica restaurata e l'architettura del Settecento romano. Edizione Bonsignori, [1995].

Villani, Marcello, „La più nobil parte”. L'architettura delle cupole a Roma 1580-1670. Gangemi Editore, [2009].

WegerhofF, Eric. „Una restituzione in senso inverso: il progetto di Carlo Fontana per il Colosseo”. Carlo Fontana 1638-1714 Celebrato Architteto. Convegno Internazionale, Roma, Palazzo Carpegna 22-24 ottobre 2014, Atti a cura di Giuseppe Bonaccorso, Francesco Moschini, Accademia di San Luca, Roma, 2017, ss. 164-169.

\section{JAN REISNER W AKADEMII ŚW. ŁUKASZA \\ ARTYSTA A POLITYKA KRÓLA JANA III \\ I PAPIEŻA INNOCENTEGO XI}

\section{Streszczenie}

Jan Reisner (ok. 1655-1713) - malarz i architekt został wysłany przez Jana III wraz z Jerzym Siemiginowskim na studia artystyczne w Akademii św. Łukasza w Rzymie. Podróż do Wiecznego Miasta, do którego dotarł 24 lutego 1678 r., odbył w orszaku księcia Michała Radziwiłła. Opiekunem i protektorem artysty podczas nauki w latach 1678-1682 był kardynał Carlo Barberini, późniejszy protektor Regni Poloniae. W konkursie architektonicznym Akademii św. Łukasza ogłoszonym w $1681 \mathrm{r}$. Reisner otrzymał pierwszą nagródę w pierwszej klasie, a nieco później został przyjęty na członka prestiżowej uczelni. Nadano mu Order Złotej Ostrogi (Aureatae Militiae Eques) oraz tytuł Aulae Lateranensis Comes, co było równoznaczne z uzyskaniem szlachectwa. Nagrodę architektoniczną przynało jury Concorso Academico w składzie: principe Akademii malarz Giuseppe Garzi, sekretarz Giuseppe Gezzi, architekci - Gregorio Tommassini i Giovanni B. Menicucci.

W Archivio storico dell'Accademia di San Luca zachowały się trzy rysunki projektowe kościoła wykonane przez Jana Reisnera piórkiem i akwarelą, przedstawiające elewację frontową, przekrój podłużny oraz rzut. Mimo że wykonane zostały na konkurs w $1681 \mathrm{r}$. opisano je z datą 1682, gdy wręczano już nagrody.

Projekt Reisnera odzwierciedlał skomplikowane tendencje w architekturze lat sześćdziesiątych i siedemdziesiątych XVII w., zwłaszcza w edukacji architektonicznej Akademii św. Łukasza. Próbowano tam pogodzić klasycyzujące tendencje propagowane przez dwór francuski z nawiązywaniem do form dojrzałego baroku rzymskiego. W konsekwencji próby połączenia cech dwóch tradycji powstało dzieło eklektyczne, tak jak i inne projekty konkursowe tworzone przez studentów Akademii św. Łukasza.

Architekt zaprojektował świątynię-mauzoleum Barberinich, na planie koła z otwierającymi się do środka ośmioma niższymi kaplicami i prostokątnym prezbiterium. W rotundowym wnętrzu wyodrębnić można trzy części: korpus z otwierającymi się kaplicami, tambur oraz czaszę z naszkicowaną kompozycją Stracenie aniołów. W środku oznaczony został ołtarz z filarowo-kolumnowych baldachimem. 
Genezę architektoniczną budowli określiły antyczne budowle: Panteon (125 r. po Ch.) oraz Muzoleum Konstancji (IV w. po Ch.). Nowożytną redakcję tego modelu otworzył Andrea Palladio, projektując Tempietto Barbaro w Maser z 1580 r. W bliższej perspektywie czasowej i terytorialnej inspiracji mogły dostarczyć Santa Maria della Assunzione w Ariccia (1662-1664) Berniniego i Notre-Dame-de-l'Assomption (1670-1676) w Paryżu projektu Charles'a Errarda. Zwłaszcza niezrealizowany projekt Carlo Fontany adaptacji Koloseum na miejsce kultu Świętych Męczenników podjął Klemens X w związku z obchodami Roku Świętego w 1675 r. W środku amfiteatru Flawiusza projektował wzniesienie kościoła w formie antykizowanej rotundy, z kopułą na wysokim tamburze i wieńcem kaplic wokół. Równie istotny był projekt Fontany centralnego kościoła w baskijskiej Loyoli (Santuario di S. Ignazio a Loyola). W barokowych realizacjach ówczesnego Rzymu znajdujemy wzory dla dekoracji architektonicznej kościoła Reisnera. W układzie i plastyce elewacji widoczne jest oddziaływanie kolumnowych fasad baroku, tak powszechnych, w różnych wariantach w dziełach da Cortony, Borrominiego i Rainaldiego. Świeżo ukończone były monumentalne, kolumnowe fasady wzniesione według projektów Carlo Rainaldiego: S. Andrea della Valle (1656/1662-1665/1666) i S. Maria in Campitelli (projekt - 1658-1662; realizacja, 1663-1667) oraz Borrominiego San Carlo alle Quatro Fontane (1667-1677). Aniołki podtrzymujące girlandy na cokołach attyki tamburu są wzorowane na dekoracji z dwóch kościołów Berniniego: S. Maria della Assunzione w Ariccia (1662-1664) i S. Andrea al Quirinale (1658-1670).

Do repertuaru dojrzałego baroku należą również oprawy okienne elewacji frontowej piętra w postaci przerwanego belkowania i z naczółkiem formie odcinków zakończonych wolutkami. Z projektu wynika, że prezbiterium miało być założone na lekko wydłużonym prostokącie o zaokrąglonych narożach i nakryte sufitem z fasetami, w przekroju zbliżonym do spłaszczonej mocno kopuły. Zbliża się ona do rozwiązań stosowanych przez Borrominiego w Collegio di Propaganda Fide i Oratorium Filipinów. Widoczne są trzy owalne okna dekorowane łuczkami o zarysie litery „C” i z żebrami wychodzącymi z wolut podstawy kopuły, które należały do charakterystycznych motywów da Cortony, przejętych od Michała Anioła. Wieńcząca latarnia otrzymała oryginalny kształt - w przekroju kontur gruszki z trzema oknami o takim samym kształcie, ujęty rozciągniętymi esowato wolutami, należącymi do kanonicznych motywów stosowanych za da Cortoną przez rzesze architektów późnobarokowego eklektyzmu.

Wraz z nauką architektury, co było w Akademii typowe, Reisner uczył się malarstwa i geodezji, dzięki którym po powrocie do Polski zyskał prestiż i znaczenie na dworze Jana III, potem u wojewody płockiego Jana Krasińskiego. Znakomicie zapowiadający się talent architektoniczny nie zabłysnął jako architekt w Polsce, choć - jak niewielu studentów Akademii św. Łukasza - dostąpił wszystkich zaszczytów jako student i absolwent.

Słowa kluczowe: Jan Reisner; Akademia św. Łukasza w Rzymie; edukacja artystyczna; kontakty artystyczne Polski z Włochami; późnobarokowy eklektyzm w architekturze; król Jan III Sobieski.

\section{JAN REISNER IN ACCADEMIA DI SAN LUCA: THE ARTIST AND THE POLITICS OF KING JAN III AND POPE INNOCENT XI}

\section{Sum mary}

Jan Reisner (ca. 1655-1713) was a painter and architect. He was sent by King Jan III together with Jerzy Siemiginowski to study art at St. Luke Academy in Rome. He traveled to the Eternal City (where he arrived on February 24, 1678) with Prince Michał Radziwiłł's retinue. Cardinal Carlo Barberini, who later became the protector of Regni Poloniae, was the guardian and protector of the artist during his studies in 1678-1682. In the architectural competition announced by the Academy in 1681 Reisner was awarded the first prize in the first class, and a little later he was accepted as a member of this prestigious university. He was awarded the Order of the Golden Spur (Aureatae Militiae Eques) and 
the title Aulae Lateranensis Comes, which was equivalent to becoming a nobleman. The architectural award was conferred by the jury of Concorso Academico, composed of the Academy's principe painter Giuseppe Garzi, its secretary Giuseppe Gezzi, and the architects Gregorio Tommassini and Giovanni B. Menicucci. In the Archivio storico dell'Accademia di San Luca, preserved are three design drawings of a church made by Jan Reisner in pen and watercolor, showing the front elevation, longitudinal section, and a projection. Although they were made for the 1681 competition, they were labelled with the date 1682, when the prizes were already being awarded. Reisner's design reflected the complicated trends in the architecture of the 1660s and 1670s, especially in the architectural education of St. Luke's Academy. There, attempts were made to reconcile the classicistic tendencies promoted by the French court with the reference to the forms of mature Roman Baroque. As a result of this attempt to combine the features of the two traditions, an eclectic work was created, as well as other competition projects created by students of the St. Luke's Academy. The architect designed the Barberini temple-mausoleum, on a circular plan with eight lower chapels opening inwards and a rectangular chancel. The inside of the rotund is divided into three parts: the main body with opening chapels, a tambour, and a dome with sketches of the Fall of Angels. Inside, there is an altar with a pillar-and-column canopy. The architectural origin of the building was determined by ancient buildings: the Pantheon (AD 125) and the Mausoleum of Constance (4th century AD). A modern school based of this model was opened by Andrea Palladio, who designed the Tempietto Barbaro in Maser from 1580. In the near future, the Santa Maria della Assunzione in Ariccia (1662-1664) by Bernini and Notre-Dame-de-l'Assomption (1670-1676) in Paris by Charles Errard could provide inspiration. In particular, the unrealized project of Carlo Fontana to adapt the Colosseum to the place of worship of the Holy Martyrs was undertaken by Clement $\mathrm{X}$ in connection with the celebration of the Holy Year in 1675. In the middle of the Flavius amphitheatre, he designed the elevation of a church in the form of an antique-styled rotunda, with a dome on a high tambour and a wreath of chapels encircling it. Equally important was the design of the fountain of the central church in Basque Loyola (Santuario di S. Ignazio a Loyola). In the Baroque realizations of the then Rome we find patterns for the architectural decoration of the Reisnerian church. In the layout and the artwork of the facades we notice the influence of the columnar Baroque facades, so common in different variants in the works of da Cortona, Borromini and Rainaldi. The monumental columnar facades built according to Carlo Rainaldi's designs were newly completed: S. Andrea della Valle (1656 / 1662-1665 / 1666) and S. Maria in Campitelli (designed in 1658-1662 and executed in 1663-1667), and Borromini San Carlo alle Quatro Fontane (1667-1677). The angels supporting the garlands on the plinths of the tambour attic are modelled on the decoration of two churches of Bernini: S. Maria della Assunzione in Ariccia (1662-1664) and S. Andrea al Quirinale (1658-1670). The repertoire of mature Baroque also includes the window frames of the front facade of the floor in the form of interrupted beams and, with the header made in the form of sections capped with volutes. The design indicates that the chancel was to be laid out on a slightly elongated rectangle with rounded corners and covered with a ceiling with facets, with a cross-section similar to a heavily flattened dome. It is close to the solutions used by Borromini in the Collegio di Propaganda Fide and the Oratorio dei Filippini. The three oval windows decorated with C-shaped arches and with ribs coming out of the volute of the base of the dome, which were among the characteristic motifs of da Cortona, taken over from Michelangelo, are visible. The crowning lantern was given an original shape: a pear-shaped outline with three windows of the same shape, embraced by S-shaped elongated volutes, which belonged to the canonical motifs used behind da Cortona by the crowds of architects of late Baroque eclecticism. Along with learning architecture, which was typical at the Academy, Reisner learned painting and geodesy, thanks to which, after his return to Poland, he gained prestige and importance at the court of Jan III, then with the Płock Voivode Jan Krasiński. His promising architectural talent did gain prominence as an architect in Poland, although - like few students of St. Luke's Academy - he received all the honors as a student and graduate.

Keywords: Jan Reisner; Accademia di San Luca; artistic education; Polish artistic contacts with Italy; late Baroque eclecticism in architecture; King Jan III Sobieski. 


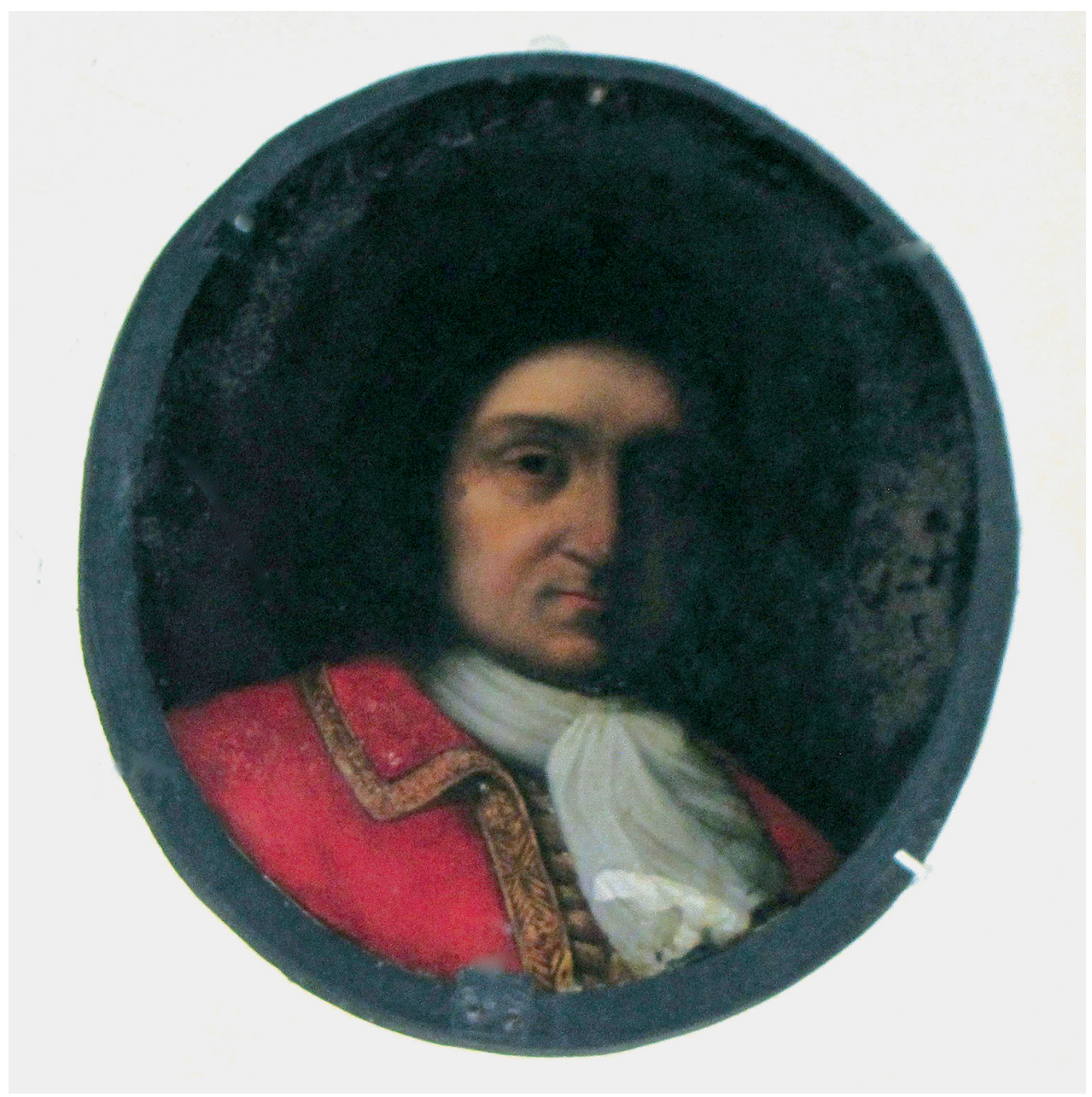

1. Portret Jana Reisnera. Kościół pw. Wniebowzięcia NMP w Węgrowie. Fot. T. Bernatowicz, 2018 


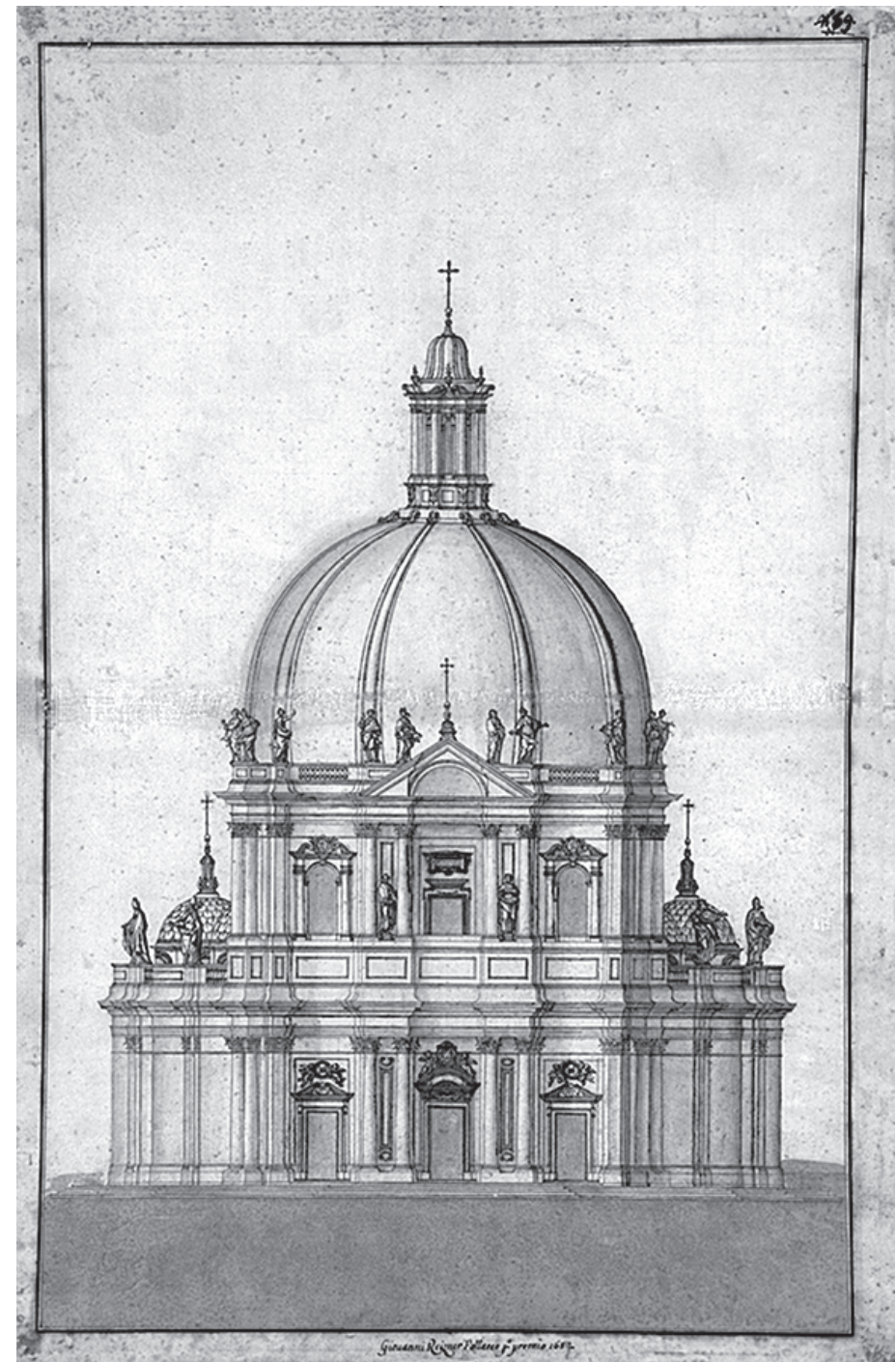

2. Jan Reisner. Projekt kościoła na konkurs w Akademii św. Łukasza w 1681. Elewacja frontowa. Oryg. AASL 


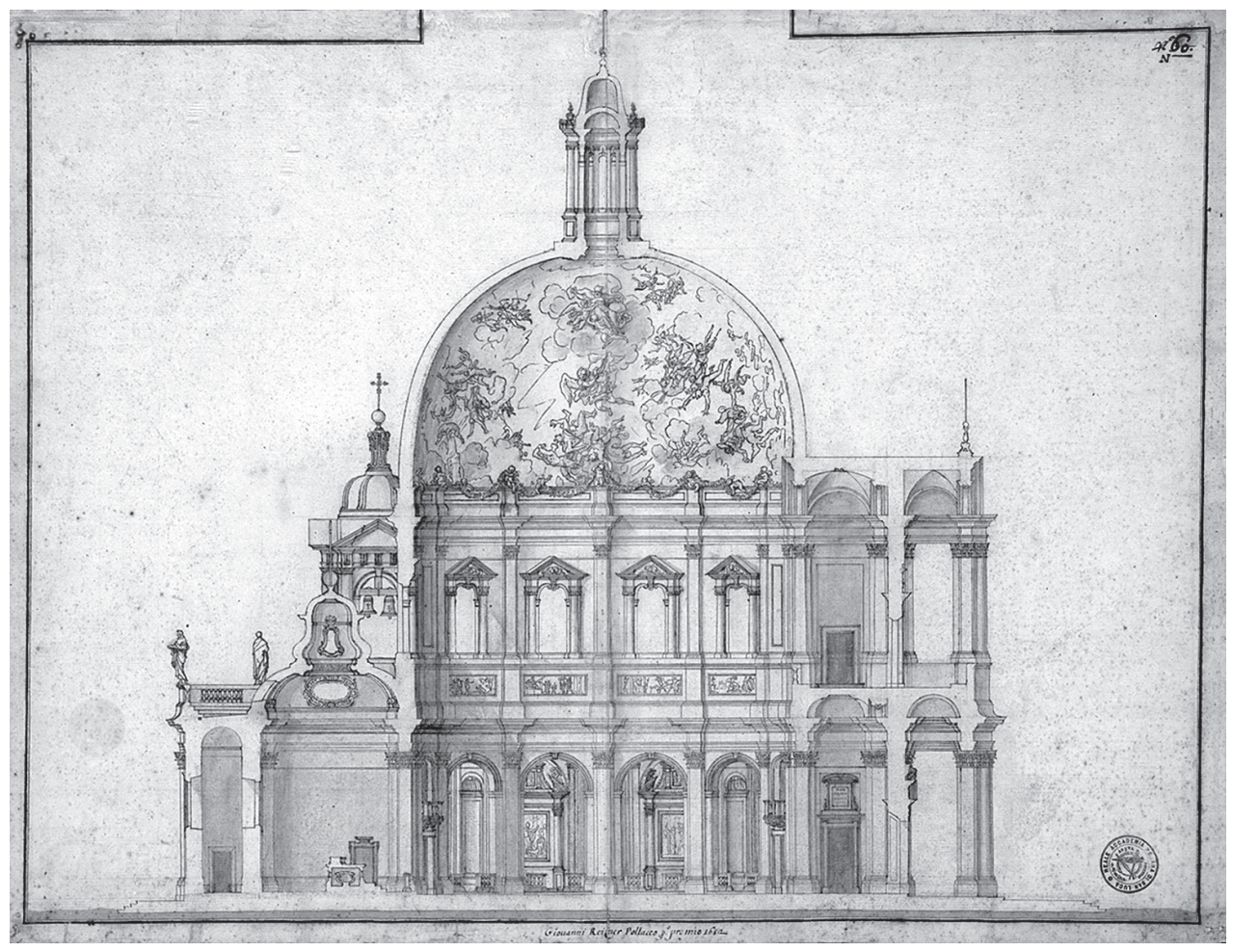

3. Jan Reisner. Projekt kościoła na konkurs w Akademii św. Łukasza w 1681. Przekrój podłużny. Oryg. AASL 


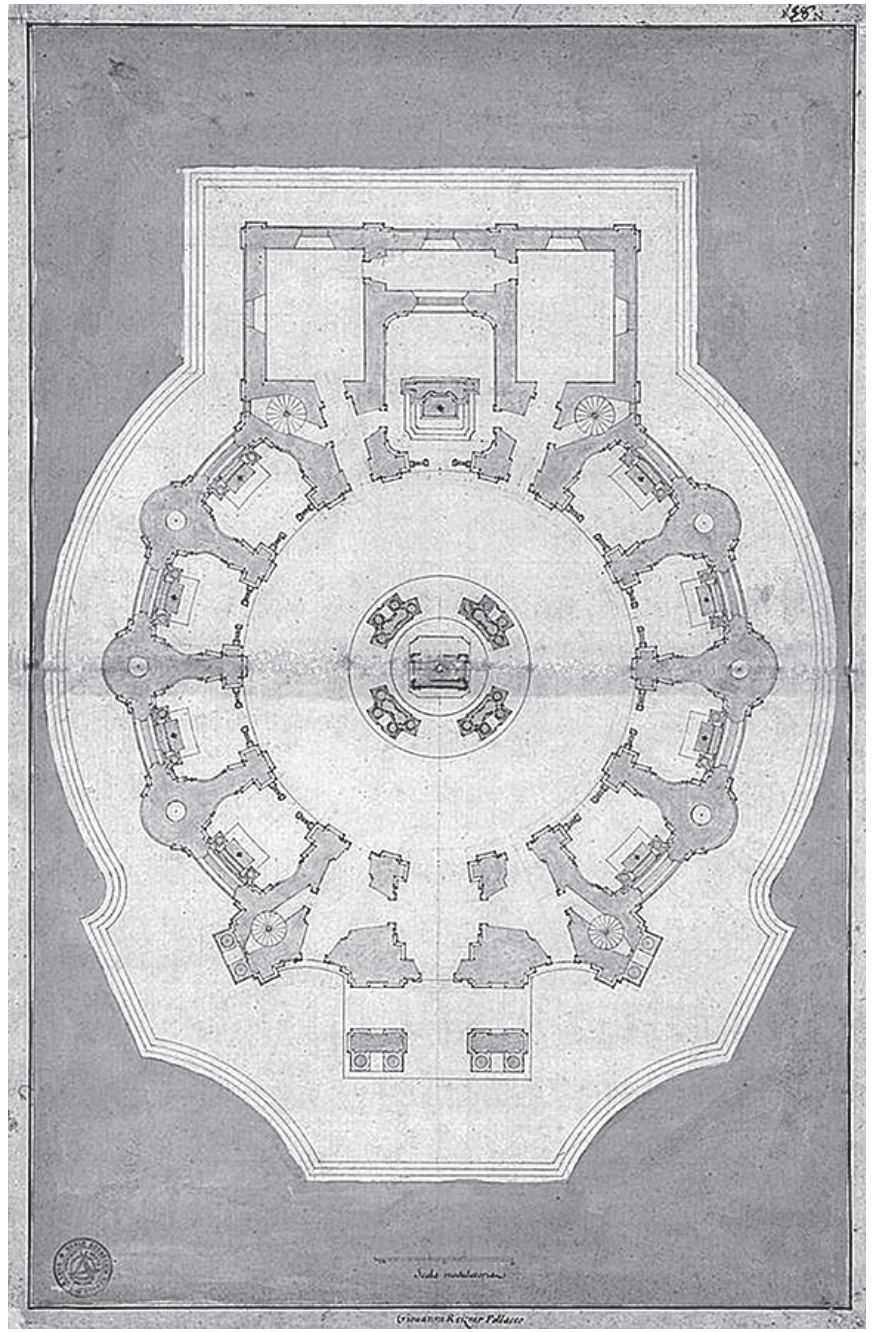

4. Jan Reisner. Projekt kościoła na konkurs

w Akademii św. Łukasza w 1681.

Rzut poziomy. Oryg. AASL 


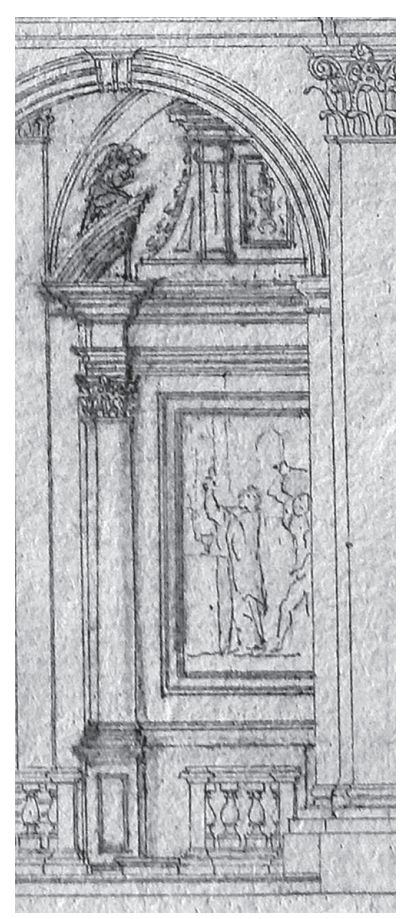

5. Jan Reisner. Projekt kościoła na konkurs w Akademii św. Łukasza w 1681. Ołtarz w kaplicy. Oryg. AASL

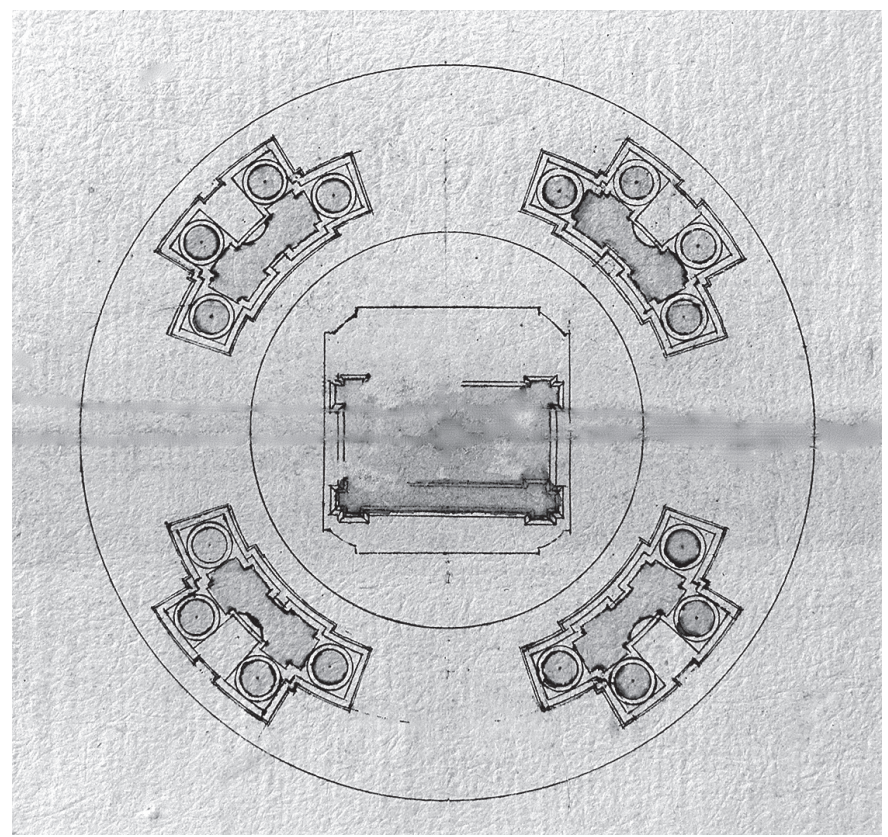

6. Jan Reisner. Projekt kościoła na konkurs w Akademii św. Łukasza w 1681. Rzut baldachimu z ołtarzem w centrum świątyni. Oryg. AASL 


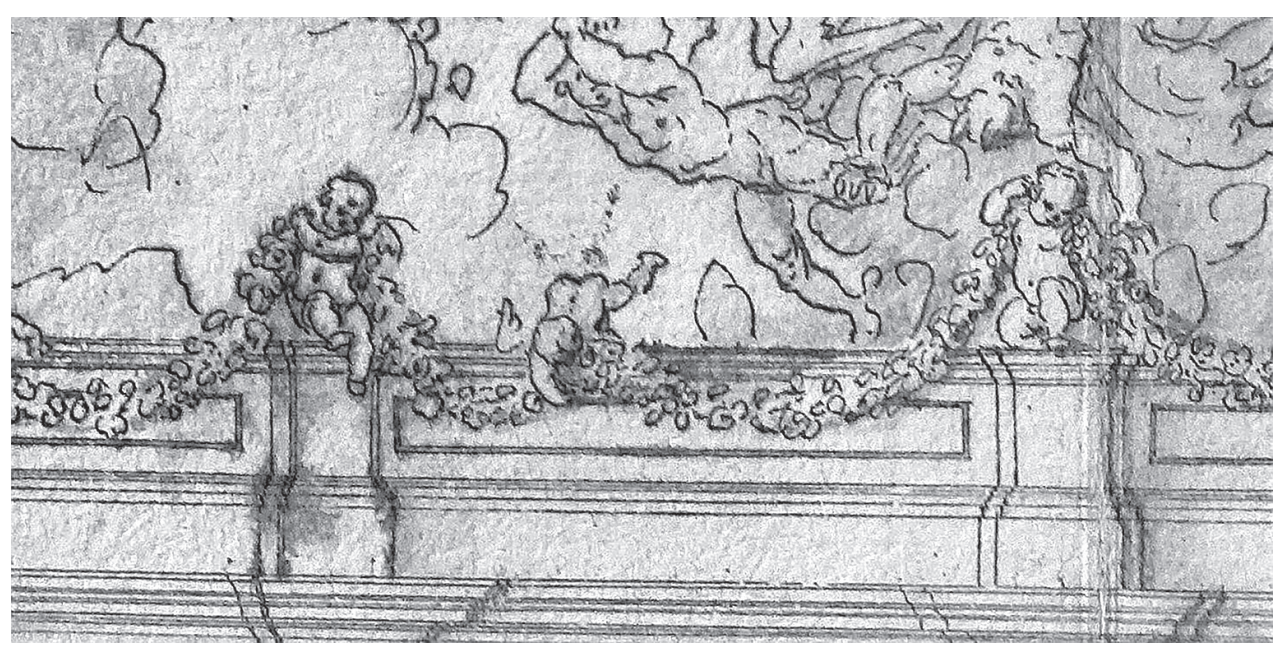

7. Jan Reisner. Projekt kościoła na konkurs w Akademii św. Łukasza w 1681. Dekoracja kopuły z puttami podtrzymującymi girlandy. Oryg. AASL

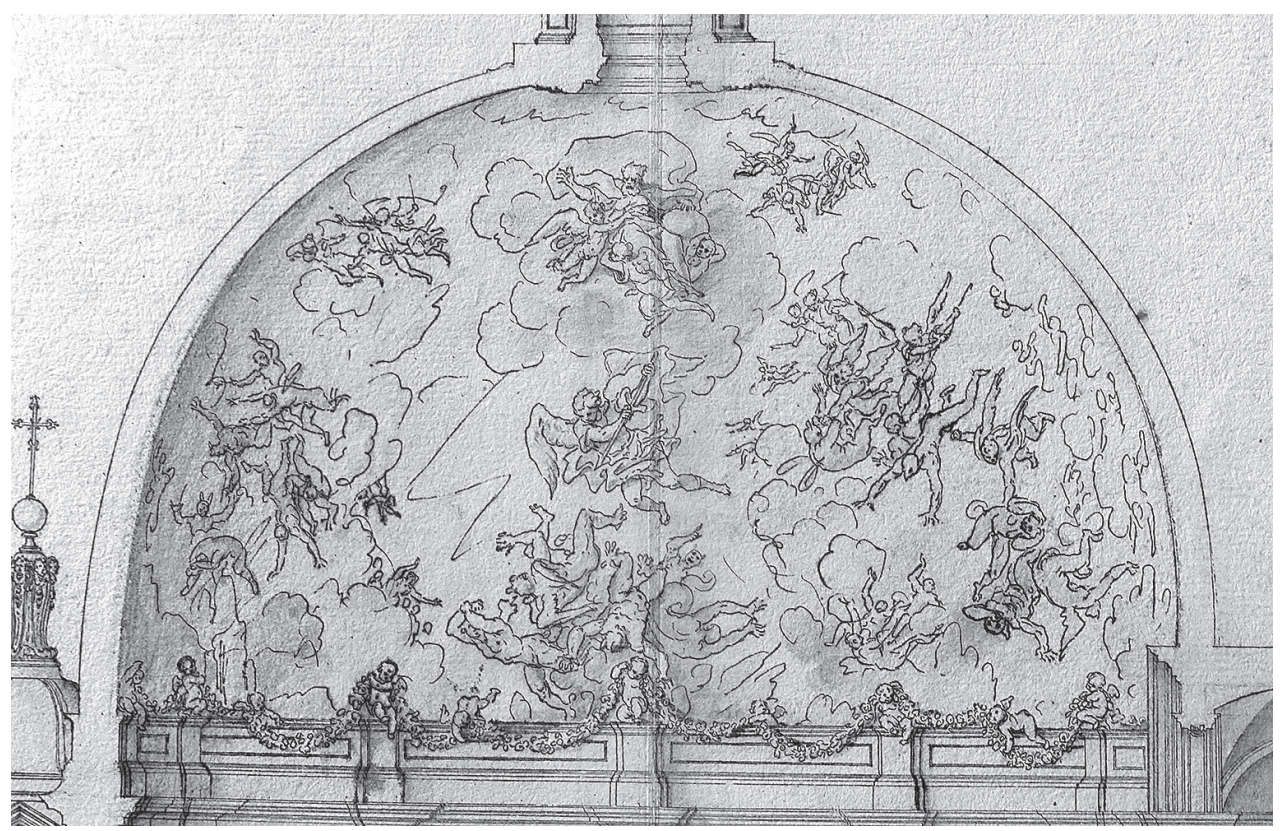

8. Jan Reisner. Projekt kościoła na konkurs w Akademii św. Łukasza w 1681. Szkic do dekoracji w kopule. Oryg. AASL 


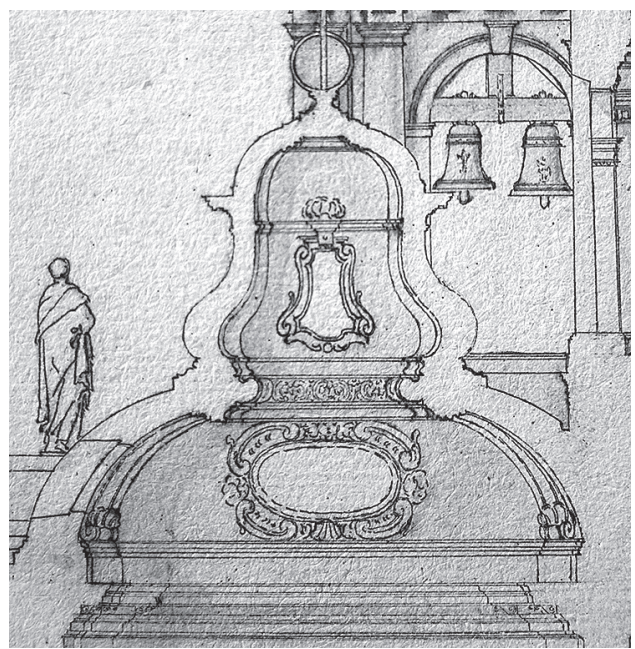

9. Jan Reisner. Projekt kościoła na konkurs w Akademii św. Łukasza w 1681. Przekrój przez kopułę i latarnię prezbiterium. Oryg. AASL

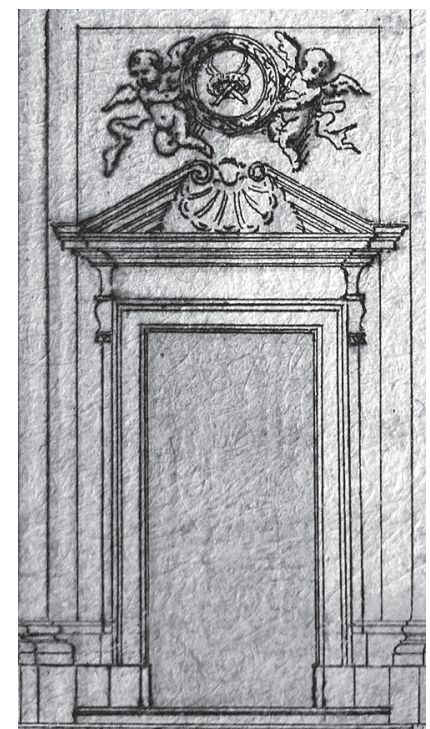

11. Jan Reisner. Projekt kościoła na konkurs w Akademii św. Łukasza w 1681. Portal boczny elewacji frontowej. Oryg. AASL

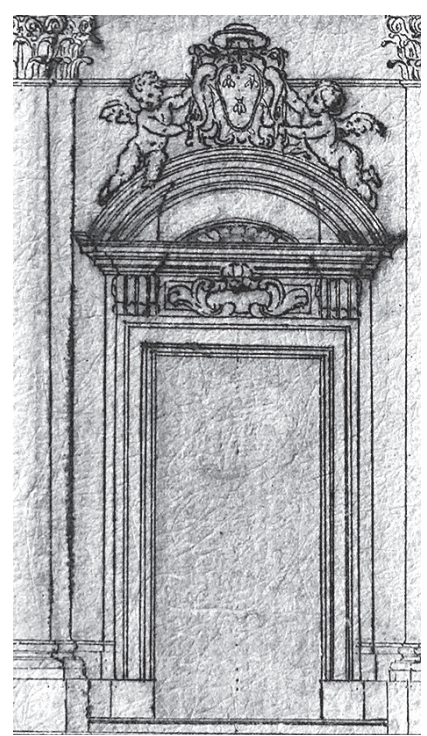

10. Jan Reisner. Projekt kościoła na konkurs w Akademii św. Łukasza w 1681.

Portal główny z herbem Barberinich. Oryg. AASL

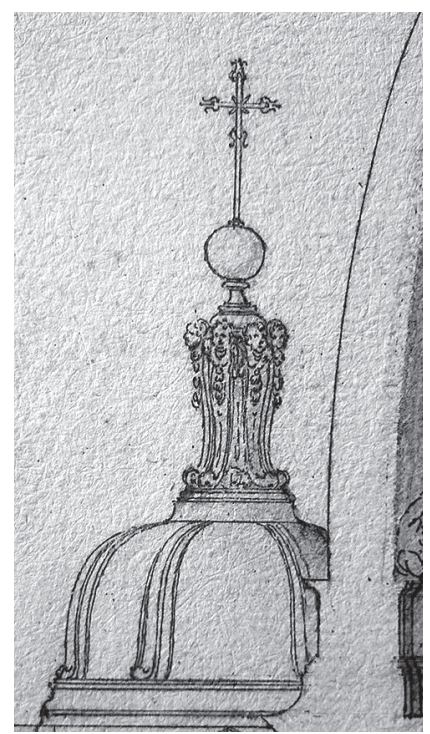

12. Jan Reisner. Projekt kościoła na konkurs w Akademii św. Łukasza w 1681.

Hełm wieży. Oryg. AASL 


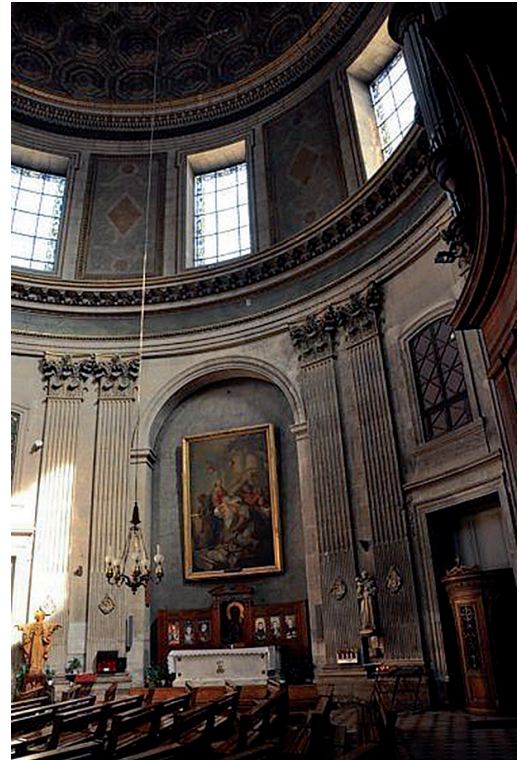

13. Charles Errard. Kościół Notre-Dame-de-l'Assomption w Paryżu z lat 1670-1676. Widok wnętrza. Fot. współczesna, ok. 2018

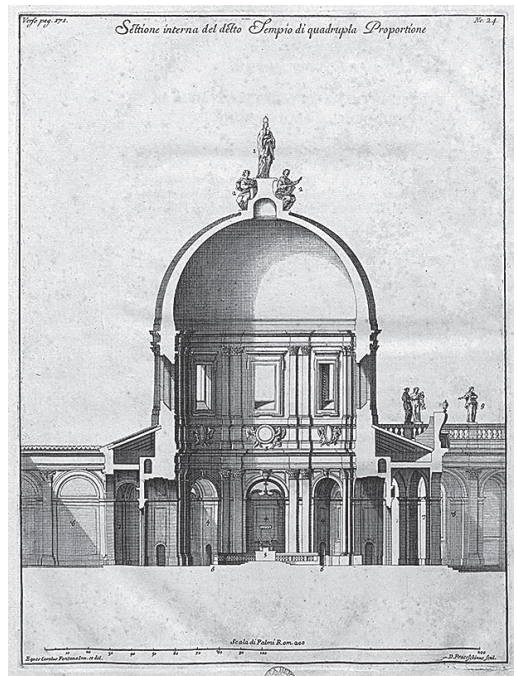

15. Carlo Fontana. Projekt kościoła Świętych Męczenników w Koloseum. Przekrój poprzeczny. Wg L'Anfiteatro Flavio descritto...1725

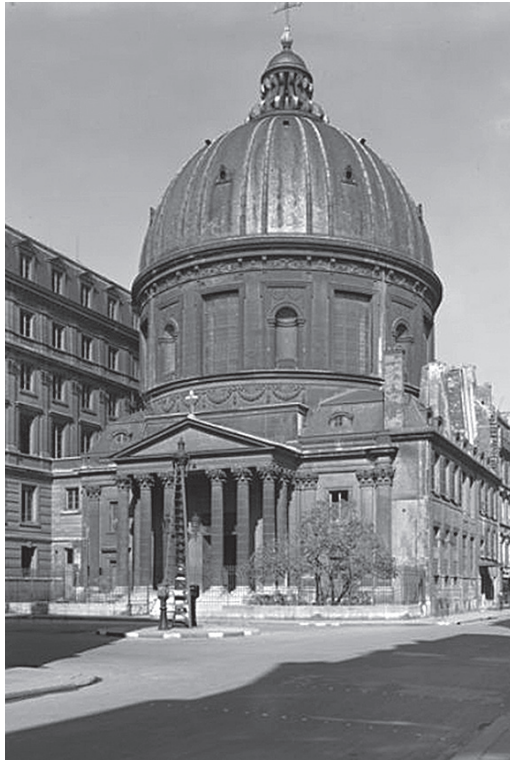

14. Charles Errard. Kościół Notre-Dame-de-l'Assomption w Paryżu z lat 1670-1676. Widok zewnętrzny. Fot. współczesna, ok. 2018

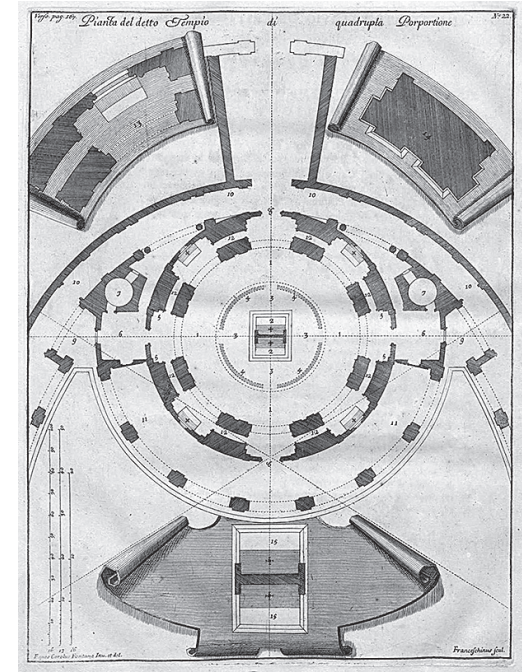

16. Carlo Fontana. Projekt kościoła Świętych Męczenników w Koloseum. Rzut poziomy. Wg L'Anfiteatro Flavio descritto...1725 


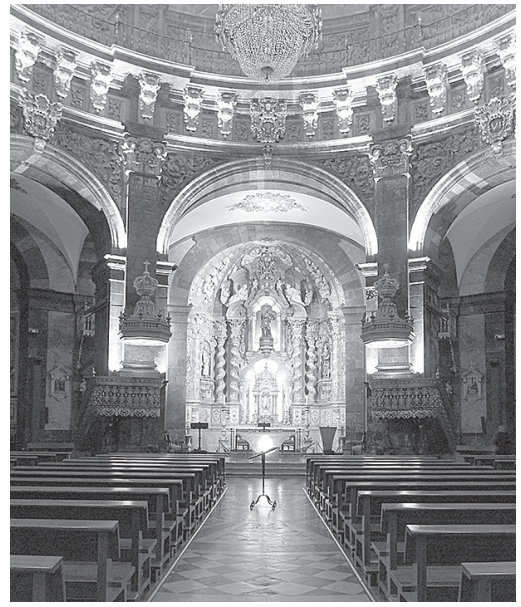

17. Carlo Fontana. Kościół w (Santuario di S. Ignazio a Loyola) (bud. od 1681 r.). Widok wnętrza. Fot. współczesna, ok. 2018

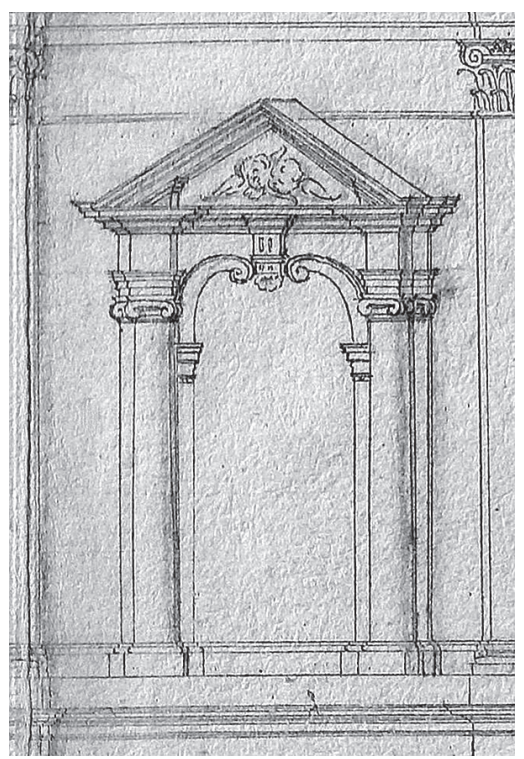

19. Jan Reisner. Projekt kościoła na konkurs w Akademii św. Łukasza w 1681. Obramienie okna wewnętrznej strony tamburu. Oryg. AASL

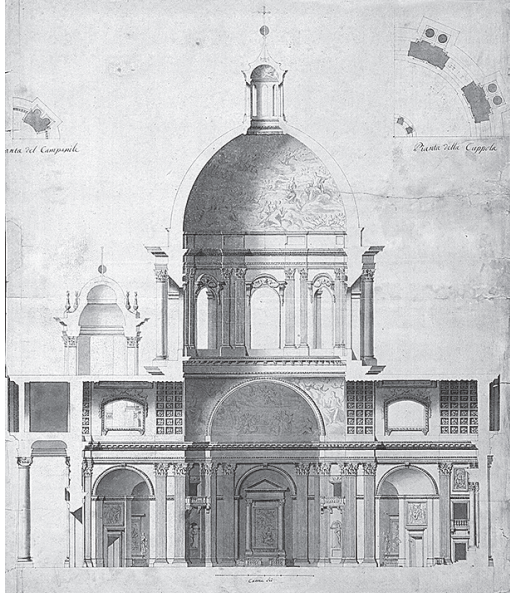

18. Simon Chupin (Simone Sciupagna). Projekt kościoła na konkurs w Akademii św. Łukasza w 1677 r. Przekrój poprzeczny. Oryg. AASL

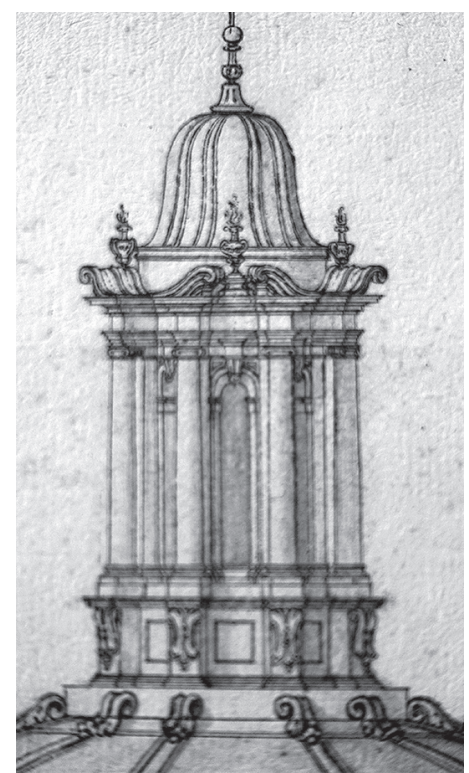

20. Jan Reisner. Projekt kościoła na konkurs w Akademii św. Łukasza w 1681. Latarnia na kopule. Oryg. AASL 